\title{
High-resolution numerical simulation of Younger Dryas glaciation in Scotland
}

\author{
Nicholas R. Golledge ${ }^{1,2}$, Alun Hubbard ${ }^{3}$ and David E. Sugden ${ }^{2}$ \\ ${ }^{1}$ British Geological Survey, Murchison House, West Mains Road, Edinburgh, EH9 3LA* \\ ${ }^{2}$ Institute of Geography, University of Edinburgh, Drummond Street, Edinburgh, EH8 9XP \\ ${ }^{3}$ Institute of Geography \& Earth Sciences, The University of Wales, Aberystwyth, \\ Penglais Campus, Aberystwyth, Ceredigion, SY23 3DB \\ email n.golledge@bgs.ac.uk, phone +44 1316671000. \\ (*Address for correspondence)
}

\begin{abstract}
We use a $500 \mathrm{~m}$ resolution three-dimensional thermomechanical ice -sheet model forced by a scaled GRIP temperature pattern to retrodict the extent of glaciers during the Younger Dryas episode in Scotland. Using empirical data from sources spanning half a century we systematically perturb temperature depression, precipitation distribution, and the amount of basal sliding to identify the parameter space that most closely reproduces the glacier margins identified from field investigations. Arithmetic comparison of predicted ice cover with empirical glacier extent enables mismatch to be quantified and an 'optimum fit' timeslice to be identified. This 'best-fit' scenario occurs with a maximum mean annual temperature depression from present of $10^{\circ} \mathrm{C}$ and steep eastward and northward gradients imposed on a modern precipitation distribution, coupled with restricted basal sliding. Even small deviations around these values produce considerably less well-fitting glacier configurations, suggesting that only a narrow range of optimal parameterisation exists. Mismatch between modelled and empirically reconstructed glacier extents occurs as a consequence of local conditions not accommodated by the model, such as wind-blown snow accumulation and lake (loch) bathymetry, and where geological evidence is equivocal. At the domain scale, however, our simulation suggests that inception of Scottish glaciers occurs rapidly, and leads to a coherent ice cap within 400 years of initial climatic cooling. According to our model, the ice cap begins to decay relatively early in the stadial, probably as a result of increasing aridity leading to net thinning and recession of many of its margins, with final and catastrophic collapse of the ice cap occurring largely within a century.
\end{abstract}


KEYWORDS: Ice-sheet modelling; Younger Dryas; glaciation; Scotland 
Numerical modelling of former ice sheets can be an effective method of inferring palaeoclimate, particularly when constrained by empirical evidence (Plummer \& Phillips, 2003; Siegert \& Dowdeswell, 2004; Napieralski et al., 2007). Ice sheet simulations thus serve to further understanding of glacial climatic conditions, whilst also providing an independent method by which to appraise glacier reconstructions based on geological or geomorphological field evidence (e.g. Van Tatenhove et al., 1996; Golledge \& Hubbard, 2005). This is particularly important in areas where current understanding is an amalgam of reconstructed ice limits published by many different workers over many decades, as is the case in Scotland (Clark et al., 2004). Numerical models allow ice-sheets to be considered in their entireity, and importantly, in all four dimensions (Sugden, 1977; Grigoryan et al., 1985; Clark et al., 1996; Sugden et al., 2002; Hubbard et al., 2005). A numerical model that is validated by empirical data in one area may thus be used to infer glacier dimensions in another, where perhaps field data is equivocal or lacking. Field data commonly reflect either isochronous events such as a stillstand of the glacier terminus, or time-transgressive processes such as streamlining or overprinting of older landforms, but rarely allow detailed insights into the evolution of the glacier through a glacial episode. However, the landform record enables model predictions to be assessed in the field, thus facilitating an iterative process from which an accurate glacier reconstruction may be derived.

The glacial landform assemblage in Scotland has traditionally been interpreted as reflecting two key events - extensive ice-sheet glaciation during the Main Late Devensian (c. 25 - 16 ka BP), and a subsequent, more restricted growth of ice during the Younger Dryas (12.7 - 11.5 ka BP) (Sutherland, 1993). The legacy of this latter episode - the Loch Lomond Readvance (LLR) - is evident primarily in the western Scottish Highlands, where landforms and sediments indicate the former presence of an ice cap centred along the main axis of the mountains and several satellite icefields around its periphery (Thorp, 1986; Bennett \& Boulton, 1993; Ballantyne, 1989, 2002; Golledge, 2007). Considerable research has been undertaken on both the extent and timing of these glaciers, enabling a reasonably complete picture to emerge (Fig. 1). A general consensus exists that the $\delta^{18} \mathrm{O}$ GRIP and GISP2 ice core records in Greenland indicate a considerable climatic downturn during the Younger Dryas, the pattern of which was closely mirrored in Scotland and which led to the re-establishment of full glacial conditions. Renewed glaciation in western Scotland probably began during the close of the Lateglacial in- 
terstadial (Clapperton, 1997; Golledge et al., 2007), and appears to have reached its maximal extent after c. 12.3 - 12.8 ka BP (Rose et al., 1988). Palaeoenvironmental data from numerous Scottish sites broadly constrain the geometry of the renewed ice masses to areas where interstadial deposits are apparently absent (Fig. 1).

\section{Objectives}

Several previous attempts have been made at glacier modelling in Scotland, some focussing on the characteristics of the Main Late Devensian ice sheet (Boulton et al., 1977; Gordon, 1979; Glasser, 1995; Hall \& Glasser, 2003; Boulton \& Hagdorn, 2006), and others specifically targetting the Younger Dryas ice cap (Payne \& Sugden, 1990; Hubbard, 1997, 1999; Starr, 2001). Of those concerned with the Younger Dryas, model resolution has varied from $1 \mathrm{~km}-5 \mathrm{~km}$, primarily governed by a limited availability of high-resolution topographic datasets and the computational resources required to solve complex algorithms over a model domain exceeding $100000 \mathrm{~km}^{2}$. In this paper we aim to:

1. Refine the work of Hubbard $(1997,1999)$ by employing a numerical model with a horizontal grid resolution of $500 \mathrm{~m}$, four times greater than previously possible, to simulate glacier extent in Scotland during the Younger Dryas.

2. Describe the basic characteristics and limitations of the model and the assumptions made in its use.

3. Use empirical palaeoclimatic data to initially force the mass balance component of the model, so as to replicate perceived stadial environmental conditions as closely as possible.

4. Assess the sensitivity of the model to pertubations in the parameters governing ice flow (principally basal sliding and internal deformation) and mass balance (temperature, precipitation volume and distribution).

5. Validate the model by attempting to reconstruct ice masses that honour as many of the maximal limits of LLR glaciers, established from empirical reconstructions, as possible.

6. Describe the palaeoclimatic and glaciodynamic conditions that combine to produce a 'best-fit' model scenario for the model domain during the Younger Dryas. 
7. Highlight areas where mismatch occurs between model predictions and the empirical record, and to offer resolutions where possible.

\section{Methods}

The three-dimensional thermomechanical model used for this experiment is modified from the one previously used to model the Younger Dryas ice cap in Scotland (Hubbard, 1997, 1999), the Last Glacial Maximum (LGM) ice cap in Patagonia (Hubbard et al., 2005) and the LGM ice sheet in Iceland (Hubbard et al., 2006). Necessary input data are a) basal topography at 500m resolution derived from NEXTMap digital elevation data and British Geological Survey bathymetric data, b) mean annual air temperature (MAAT), and c) present precipitation pattern. The two climatic components are derived from regression analysis of modern temperature and precipitation patterns within the model domain, based on the United Kingdom Climatic Impacts Programme (UKCIP) baseline climate (Purves \& Hulton, 2000). Mass balance is driven by an elevation-related Positive Degree Day (PDD) scheme based on that of Laumann \& Reeh (1993) that derives total melt from integrated positive temperatures. Despite the limitations of such schemes (van der Veen, 2002), their general ability to simulate glacier responses in contemporary environments (e.g. Braithwaite, 1995; Jóhannesson et al., 1995) lends confidence in their use. Precipitation is distributed evenly throughout the model year and daily temperature is calculated from mean annual temperature using a sinusoidal function that determines the standard deviation of mean July temperature. The model is iterated by manually perturbing MAAT with a 20-year GRIP-forced ELA depression scaled to Scottish palaeotemperatures, and by introducing spatial gradients to the precipitation distribution. Ice flow occurs through internal deformation and Weertman (1964)-type sliding when basal temperatures reach the pressure melting point, and which is adjusted with a dimensionless scaling factor. Longitudinal stresses become increasingly important in high resolution models such as the one used here, and are computed using an empirically validated ice-stretching algorithm (Hubbard, 2000). Calving is accomodated using an empirical function related to water depth (Brown et al., 1982), which although simplistic compared to more complex relationships (e.g. Benn et al., 2007a,b), does at least offer a reasonable approximation of calving loss with minimal computation. Given the limited extent of tidewater margins of the Younger Dryas ice cap, the use of this simple function in preference to the more complex solutions is unlikely to produce significantly different overall results, but may be a possible 
area for future model refinement. Key variables and their parameterization are described in Table 1; other variables governing ice flow and mass balance calculations can be found in Hubbard (2006) (Table 1).

Given the above boundary conditions, distribution grids for ice-surface elevation were calculated by solving at a 0.02 year time step from initial ice-free conditions. The model offers an approximation of reality and necessarily involves simplifying assumptions that are common to most modelling experiments. In particular, the spatial resolution and smoothing of basal topography may produce some inaccuracy, and the lack of terrestrial water bodies (including proglacial lakes) will locally neglect calving-related ablation. The mass balance model used may have a degree of error, and furthermore snow accumulation does not take into account mass redistribution by wind-blow or avalanching. Assuming uniform rheology of the glacier bed may similarly mask complex ice dynamics at a local scale. However, only a very small proporation of the glaciated area is underlain by unconsolidated deposits thicker than a metre or two (mainly near glacier terminii), and at the domain scale these local differences become less critical.

\section{Model parameterization}

Any attempt to realistically model former glaciers must be guided by empirical data as far as possible. To that end, consideration of previous palaeoenvironmental studies is given below, with the aim of establishing plausible ranges for the distributions governing mass balance (temperature, precipitation amount and spatial gradients), as well as other influential factors such as stadial sea level and typical geothermal heat flux.

\section{Palaeoenvironment}

The Lateglacial period (c. 11.5 - 15 ka BP) in Britain was one of 'marked climatic instability' (Mayle et al., 1999, p421) characterized by 'abrupt and intense climatic changes' throughout northwestern Europe (Witte et al., 1998, p435). Both ice core data and palaeoecological proxies indicate that only a brief warm period occurred during the interval 14-15 ka BP at the close of the Main Late Devensian, perhaps lasting no more than 500 years, before stepwise cooling ensued during the Older Dryas (c. 13.7 - 14.5 ka BP, Clapperton, 1995). This Bond cycle was temporarily interupted by a warm period from c. 13.1 - $13.7 \mathrm{ka}$ BP prior to the high magnitude thermal decline marking the onset 
of the Younger Dryas stadial. Cold conditions persisted in Greenland until 11.6 ka BP (Severinghaus et al., 1998; Alley, 2000), after which very rapid warming of $5-10^{\circ} \mathrm{C}$ took place, perhaps in as little as 1-3 years (Dansgaard et al., 1989; Alley et al., 1993; Alley, 2000). During the 1200-1300 years of full-glacial conditions, the climate throughout the North Atlantic region may have experienced considerably greater seasonality than at present (Denton et al., 2005), most probably related to a reduction in strength of the thermohaline circulation that led to a southward migration of the oceanic polar front to below $50^{\circ} \mathrm{N}$ (Ruddiman \& McIntyre, 1981; Bard et al., 1987; Isarin \& Renssen, 1999) and the spread of winter sea ice into lower latitudes (Alley, 2000). Sea-surface temperature and salinty oscillated frequently during this period, however, as a consequence of decadal-scale incursions of warm and relatively saline water from lower latitudes (Kroon et al., 1997). Residual isostatic depression following recession of the Main Late Devensian ice sheet produced stadial sea levels on the west coast of Scotland slightly higher than present at 5 - $11 \mathrm{~m}$ above sea level (a.s.l) (Gray, 1974, 1978; Gray \& Lowe, 1977; Peacock et al., 1977; Shennan et al., 1999). Geothermal heat flux across the model domain varies little, and for simplicity is kept constant at $55 \mathrm{Wm}^{-2}$ (Rollin et al., 1993).

\section{Scottish palaeoclimate}

The calculation of Lateglacial palaeotemperatures through regression analysis has become possible due to the close empirical relationship between the occurrence of individual chironomid taxa and summer surface-water temperature, and use of the mutual climatic range (MCR) method of relating coleopteran assemblages to mean maximum and minimum air temperatures (Atkinson et al., 1987; Brooks \& Birks, 2000). Palaeoecological datasets used as UK temperature proxies appear to be in good agreement with climatic patterns identified in the GRIP data (Fig. 2) (Atkinson et al., 1987; Mayle et al., 1999; Brooks \& Birks, 2000), suggesting that oscillations throughout the North Atlantic were broadly contemporaneous, even if their relative magnitudes may have differed. Such an association is also bourne out by the close match between the pattern of sea-surface temperature variation west of Scotland, and the Greenland $\delta^{18} \mathrm{O}$ record (Kroon et al., 1997). Several Lateglacial sites in the UK have yielded important data pertinent to our understanding of climate change through this period, generally indicating a stadial mean July temperature of c. $8-10^{\circ} \mathrm{C}$ at sea level (Witte et al., 1998; Brooks $\&$ Birks, 2000) and winter temperatures no warmer than c. $-13.5^{\circ} \mathrm{C}$ (Witte et al., 1998). 
A mean annual temperature of -2 or $-3^{\circ} \mathrm{C}$ can thus be approximated, representing a cooling of around $10-14^{\circ} \mathrm{C}$ on present values. Although some of these proxies tend to overestimate mean temperatures, particularly in the case of the coleoptera, and thus may not entirely reflect the full seasonal range of former climatic conditions (Isarin \& Renssen, 1999; Denton et al., 2005), these values are comparable to those calculated by Benn \& Ballantyne (2005) based on glacier reconstructions in the West Drumochter hills. Clapperton (1997) used modern climatic data to derive a 'topographic glaciation threshold'. This was calibrated against $\delta^{18} \mathrm{O}$ data from the GRIP ice core (in which $1 \%$ change in $\delta^{18} \mathrm{O}$ represents a temperature drop of about $1.5^{\circ} \mathrm{C}$ in Scotland) (Fig. 2), allowing him to identify periods when conditions were cold enough for glaciers and ice sheets to have formed in the Scottish Highlands. Despite the generalizations implicit in this approach, the implication that much of the interstadial was cold enough for ice to have accumulated is compelling.

\section{Cryospheric response in Scotland}

The response of glaciers in Scotland to climate change during the Lateglacial period remains somewhat enigmatic, due partly to a lack of high-resolution dates from relict glacial landforms. Instead, the chronology of Main Late Devensian ice sheet recession and the subsequent Younger Dryas readvance is constrained largely by ${ }^{14} \mathrm{C}$ dates from organic material related to either the Lateglacial interstadial, or early Holocene. These uncertainties aside, numerous attempts have been made to gain palaeoclimatic insights from empirical reconstructions of glaciers ascribed to the YD throughout Scotland, principally through calculations of the Equilibrium Line Altitude (ELA) of former glaciers using the methods of Sissons (1974), Sissons \& Sutherland (1976), and Osmaston (2005). These techniques are validated to some extent by their grounding in empirical observations (e.g. Sutherland, 1984; Ohmura et al., 1992), but the derived ELAs and palaeoclimatic inferences may still be erroneous in areas where either the hypsometry of the glacier is misidentified (cf Rea et al., 1998), or where the margins used for area calculations remain undated. An additional problem with reconstructions based on the Ohmura et al. (1992) dataset is that the concept of continentality is ignored; the polynominal relationship linking precipitation and temperature effectively represents an approximation of a global dataset, which includes highly maritime glaciers in New Zealand as well as much more continental glaciers in the Canadian 
high Arctic. Model experiments demonstrate that, for any given summer temperature, greater seasonal variations result in lower mean annual temperatures and hence a reduced ablation season (Hughes \& Braithwaite, 2008). Consequently, accumulation (or precipitation) calculations based on Ohmura et al. (1992) will tend to overestimate the volume required to maintain glacier mass balance at the reconstructed ELA, since they erroneously assume greater ablation.

Table 2 shows inferred climate data from both palaeoglaciological and palaeoecological studies for areas pertinent to the present study, together with modern reference values. These varied sources demonstrate considerable evidence for climatic cooling during the Younger Dryas, in particular highlighting the bias of cooling in the winter, when estimated palaeotemperatures may have been as low as $-20^{\circ} \mathrm{C}$. Cooling during the summer months was less severe, but was nonetheless sufficient to produce stadialaveraged mean annual temperatures around $8^{\circ} \mathrm{C}$ colder than present. Additionally, data from palaeoglaciological reconstructions in eastern parts of Scotland (e.g. Sissons \& Sutherland, 1976) indicate that precipitation there was considerably less than at present. The consequently west-skewed precipitation distribution led to a southwest to northeast precipitation reduction of 70-80\%. This would have favoured high accumulation rates in western Scotland, closest to the influence of maritime air masses, but led to considerable aridity further east largely as a result of the reduced capacity of cold air masses to hold and transport moisture.

\section{Model strategy}

Whilst a good body of palaeoclimatic data clearly exists, few methods are available with which to appraise its reliability. Numerical modelling offers the opportunity to tackle the inter-relationship between palaeoenvironment and glacier extent and to generate both plausible and implausible glacier configurations through the evolution of the model run. Through systematic perturbation of forcing factors, many different ice sheet configurations can be generated and each assessed for their degree of fit to empirical data. Controlled iteration of the model thus enables continual refinement of the output towards a 'best-fit' scenario. Some modelling studies employ sophisticated methods of margin-matching in order to accurately reproduce mapped glacial limits as closely as possible (e.g. Arthern \& Hindmarsh, 2003; Tarasov \& Peltier, 2004), but in contrast 
to our experiments, these other examples start with the a priori assumption that the empirical limits are correct. Here, we aim specifically to test the mapped limits, and thus avoid localised 'hand tuning' (Tarasov \& Peltier, 2004, : p373). The sensitivity of our model to key parameters is gauged by the relative discrepancy between the results of each incremental parameter change and those of an optimum simulation. In this manner both the reliability and quality of model fit may be inferred, as well as the relative importance of margin mismatches. Above all, the model provides an important connection between theoretical glaciological processes and the nature of the observed landform record.

\section{Results}

\section{Sensitivity tests}

Each of the following experiments aimed to reduce the degree of mismatch between the best result of the previous experiment and the empirical record. This involved a considerable number of model runs and parameter iterations, commonly involving very small, incremental changes to individual parameters. Complex feedbacks within the climate system, however, preclude the possibility of completely isolating each parameter in turn, and thus the possibility remains that controlled changes to one variable may also produce unknown changes in another (e.g. changing temperature and its effect on precipitation). Thus, whilst they constitute an essential component of modelling methodology, and indeed, the only pragmatic option from a computational point of view, sensitivity experiments must be interpreted with some caution.

It is neither necessary nor practical to describe every configuration of model parameters that were tried; instead a key selection of the results from each experiment are presented, in order to convey overall patterns and trends. For the step cooling experiments ( 1 and 2), a model run of 1500 years was chosen, in order to broadly reflect the lifetime of the Younger Dryas. Where a scaled GRIP temperature forcing was employed (experiments 3-5), each model run was 4000 years, from 15 -11 ka (ice-core years) BP.

\section{Experiment 1: Step cooling with present precipitation conditions:}

A suite of initial model runs aimed to establish the degree of influence exerted by the mass balance parameters on glacier location, volume, and area. In these experiments, 
a series of MAAT step coolings of values consistent with those inferred from previous studies (Table 2) were applied across the model domain, using a modern precipitation distribution. Figure $3 \mathrm{~A}$ shows ice conditions after 500 years under five different cooling scenarios. Under a $6^{\circ} \mathrm{C}$ cooling (compared to modern temperatures), the resultant ice masses are disparate and located only over the main mountain massifs, but with an $8^{\circ} \mathrm{C}$ cooling these ice centres are coalescent and form an extensive ice cap not entirely dissimilar to the 'Highland Readvance' glacier configuration proposed by Charlesworth (1955) ('Stage M', Fig. 1). With more severe cooling of $10^{\circ} \mathrm{C}$, a considerable ice sheet develops over Scotland. Cooling in excess of $10^{\circ} \mathrm{C}$ results in complete glaciation of the entire landmass and coastal fringes. Figure $4 \mathrm{~A}$ illustrates the growth trajectories of glacier area, volume, and mean thickness for each temperature scenario for the duration of the model run (1500 years). Under the $6^{\circ} \mathrm{C}$ cooling, the majority of ice accumulation occurs within the first 200-300 years, after which the glaciers appear to stabilise and continued expansion is very slow. With an $8^{\circ} \mathrm{C}$ cooling, glaciers expand quickly but continue to thicken when lateral expansion begins to slow, producing ice caps that do not reach equilibrium even after 1500 years. At colder temperatures both glacier area and volume initially increase rapidly but come close to steady state after 800-1000 years.

These results illustrate the sensitivity of the model to a step cooling, principally highlighting the strong influence exerted by topography on ice sheet growth. The results are somewhat at odds with the geometry of reconstructed LLR glaciers, particularly in central and southern areas, and thus require refinement.

Experiment 2: Step cooling with imposed precipitation gradients:

In order to more closely replicate the empirical record of glaciation, the distribution of precipitation is modified through the imposition of west to east and south to north gradients. Systematically altering the latitudinal and longitudinal ranges within which these gradients operate provides an important additional control on mass balance forcing, enabling gradual iteration of the mass balance field towards one that produces a better fit (Fig. 3B). As with experiment 1, the results show comparatively restricted glacierization with a step cooling of $6^{\circ} \mathrm{C}$, but with an $8^{\circ} \mathrm{C}$ cooling a coherent ice cap develops within 500 years. The impact of the imposed precipitation gradients is clearly apparent in the much altered spatial pattern of accumulation, and the main ice mass more closely resembles the Younger Dryas glacier configuration of the western Highlands 
(Fig. 1). Further cooling of $10-15^{\circ} \mathrm{C}$ ultimately tends toward complete terrestrial ice cover, with the imposed gradients producing a rather implausible west-skewed dome in an expansive ice sheet. The imposition of gradients with which to control the pattern of accumulation therefore appears to be effective over a range of temperature depressions, but functions most sensibly in these experiments within a narrow range $\left(\right.$ c. $\left.8-10^{\circ} \mathrm{C}\right)$.

When precipitation distribution is controlled by the gradients described above, net ice volume at any given temperature depression is reduced, accumulation occurs at a slightly slower rate, and mean ice thickness also decreases (Fig. 4B). The latter becomes more evident at temperature depressions below $10^{\circ}$, due to the skewed volume-to-area distribution that occurs.

\section{Experiment 3: Scaled GRIP temperature depression:}

Step cooling experiments are useful in identifying the sensitivity of the model to both the amount of precipitation, and its distribution. However, the close correlation between the patterns of palaeoenvironmental changes in Scotland and those reflected in the GRIP ice core suggest that a uniform cooling throughout the Younger Dryas is not realistic. To better reproduce the likely climatic conditions affecting Scotland during the whole of the Lateglacial period, a time-series file representing ELA depression (relative to maximum conditions) was calculated from the 20 -year GRIP $\delta^{18} \mathrm{O}$ data (Johnsen et al., 2001), based on the difference between a present value of -35\% (Clapperton, 1997) and values in the period 11-15 ka BP. This 20-year temperature pattern was then used to force the model by scaling it according to the range of temperature depressions represented by the MAAT values inferred from the palaeoclimate studies in Table 2. The precipitation gradients imposed during Experiment 2 to restrict eastern glacier build-up are again applied in this scenario.

Figure 5A illustrates the effect on glacier build-up of GRIP-forced climatic variability scaled to a range of plausible palaeotemperature depressions. The time-slice shown is 2500 model years, broadly equivalent to $12.5 \mathrm{ka}$ BP. Comparing these results with those produced under step-cooling scenarios (Fig. 3) it can be seen that temperature drops of $6^{\circ} \mathrm{C}$ and $8^{\circ} \mathrm{C}$ give rise to small ice masses located only over the higher hills, and generally only in the west of Scotland as a result of the imposed precipitation gradients. There is a clear difference between the results of $8^{\circ} \mathrm{C}$ step cooling and the GRIP experiment scaled to $8^{\circ} \mathrm{C}$ (Figs. $3 \& 5 \mathrm{~A}$ ). This is due to the variability in ELA depression through 
the Younger Dryas; a climatic minimum was reached early in the stadial but was shortlived, and in fact the majority of the episode was slightly milder (Fig. 2). Consequently it is with a scaling factor of $10^{\circ} \mathrm{C}$ that the most reasonable glacier pattern develops, composed of a western ice cap along the main mountain chains and satellite icefields in Arran, Mull, Skye, Assynt and the central Highlands. Scaling factors greater than $10^{\circ} \mathrm{C}$ lead to excessive ice build-up at low altitudes and the growth of an expansive ice cap or ice sheet that greatly exceeds the empirical limits.

Whilst the spatial extents of glaciers shown in Figure 5A may resemble those produced under step cooling conditions, Figure 6A dramatically illustrates the much more complex process of ice build-up that occurs under the GRIP-forced scenarios. Several trends are apparent in all of the runs:

1. ice accumulation occurs during the transition into the Lateglacial Interstadial from the Main Late Devensian 15 - 14.6 ka BP (0 - 400 model years), and is terminated by abrupt warming.

2. an ice-free period occurs from 14.6 - 14.2 ka BP (400 - 800 model years).

3. regrowth of ice occurs rapidly from $14.2 \mathrm{ka}$ BP (800 model years), marking the beginning of a period of glacier fluctuation that lasts for 1200-1400 years during the latter half of the interstadial.

4. onset of the Younger Dryas at c. 13 ka BP (c. 2000 model years) is characterized by an expansion of ice that began accumulating during the preceding millennium.

5. rapid deglaciation occurs within a period of a few hundred years at the end of the Younger Dryas, leading to ice free conditions by 11.6 - 11.4 ka BP (3400 - 3600 model years) for the milder scenarios, and 11.4 ka BP (3600 model years) or later for more severe conditions.

In addition to these general patterns, the following aspects of glacier evolution can be inferred from Figure $6 \mathrm{~A}$. Temperature scalings of less than $10^{\circ} \mathrm{C}$ produce ice masses that seem unable to grow effectively, that is, accumulation during cold spells is quickly matched by ablation during periods of a rising ELA, resulting in little or no net increase in ice mass. Conversely, ice growth under temperature depressions greater than $10^{\circ} \mathrm{C}$ appears to continue throughout the warmer oscillations of the Younger Dryas, producing steady volumetric increases that are maintained by fluctuations in area and mean thickness. This implies the existence of a threshold in ice geometry, beyond which an ice mass is able to effectively buffer itself from climatic perturbations of the magnitudes 
occuring through the Younger Dryas. The ability to do this appears to lie in the control exerted by the interaction of topography and climate on the dynamic behaviour of an ice mass, leading to thickening in higher areas due to a greater likelihood of snowfall, whilst receding elsewhere where rainfall dominates. Indeed, the results show that at temperature scalings of less than $10^{\circ} \mathrm{C}$, ice extent and volume decline steadily through the milder conditions of the mid - late stadial, whereas ice masses evolving under temperature scalings colder than this maintain considerably more stable extents over the same period.

In summary, the GRIP-forced model scenarios provide considerably more information on the dynamic nature of glacier evolution than the step-cooling experiments. They show a clear bifurcation in glacier behaviour between relatively mild conditions (temperature scaling $\leq 8^{\circ} \mathrm{C}$ ) and more severe conditions (scaling $\geq 10^{\circ} \mathrm{C}$ ).

\section{Experiment 4: The role of basal sliding:}

Further experiments introduce variability in the sliding factor, (the ability of ice to move at its bed as well as through internal deformation), to determine the sensitivity of the model to glaciodynamic changes. Where basal sliding occurs, its effectiveness is linked to bed roughness, thus the higher the sliding factor, the greater the ease with which ice can flow over obstacles. Figure 5B illustrates the effect of a range of sliding factors on the geometry of the ice cap, using the precipitation gradients gleaned from Experiment 2 and the GRIP climate pattern from Experiment 3 at its optimum scaling of $-10^{\circ} \mathrm{C}$. The differences between runs are more subtle than in previous experiments, but consistent trends are nonetheless evident. Using the results of Experiment 3 (scaling $=-10^{\circ} \mathrm{C}$, sliding $=0$ ) as a comparator, the scenarios shown in Experiment 4 show that an increase in basal sliding leads to:

1. greater horizontal spreading of the entire ice mass, producing more extensive ice cover of the domain.

2. thinner ice cover, with more nunataks becoming evident within the main ice mass.

3. more expansive outlet glaciers, for example the Loch Lomond glacier in the south of the domain.

4. further advance of terrestrial glaciers into low-lying areas, within the ablation zone. 
5. greatly enlarged marine margin along the west coast, with outlet glaciers from the mainland beginning to coalesce with those on Mull.

The changes that occur as a result of enhanced basal sliding are more clearly seen in time-series plots of ice mass geometry (Fig. 6B). Through the model run, overall ice extent (shown by the 'area' plots) varies according to temperature depression, as expected. Interestingly, however, the largest differences between scenarios occur during relatively warm periods, when greatest ablation occurs. During cold phases, particularly during the Younger Dryas episode, total ice extent becomes remarkably consistent between all of the sliding scenarios. A similar pattern can be seen in the early phases of the ice volume plots, although differences increase beyond 3000 model years with higher sliding scenarios producing slower increases in total ice volume. Ice thickness data shows the effect of these different responses on ice mass evolution, with the highest sliding values producing the thinnest ice masses overall.

In summary, because ice masses with no basal sliding behave as non-linear viscous bodies deforming at a rate largely governed by their temperature, surface slope, and thickness, any increase in the amount of basal sliding greatly facilitates the lateral expansion of outlet glaciers. Higher sliding values produce greater velocities in outlet glaciers, which in turn steepen ice surface gradients towards accumulation areas and so increase local driving stresses. Consequently, ice flux from the interior is enhanced, leading to a more extensive but generally thinner ice mass than one moving by ice creep alone. Most importantly with respect to our aim of replicating empirical margins, the geometry of the simulated ice masses changes considerably with variation in sliding, most particularly in their overall thickness. In attempting to reproduce a main ice cap whose ice thickness agrees with empirical data, and whose outlet glaciers most closely match moraine limits, it is necessary to impose a sliding factor less than five (Fig. 6B), but greater than zero (Fig. 6A).

\section{Experiment 5: Optimum fit scenario:}

Iteration of the above parameters in a systematic and incremental manner allows the results of numerous experiments to be refined. For example, in Experiment 3, the initial precipitation boundary conditions led to a temperature-specific bifurcation in ice sheet growth. At the $10^{\circ} \mathrm{C}$ 'optimum' scaling, this bifurcation produces continued expansion 
of the main ice cap despite the overall warming trend in the scaled GRIP temperature field. The ice cap becomes increasingly focussed around the principal accumulation areas in the southwest of the domain, and begins to exceed the limits indicated by the landform record. Palaeoclimatic studies in Skye have shown that aridity may have played a key role during maximum stadial conditions, not only limiting glacier expansion but actually propagating deglaciation (Benn et al., 1992). Consequently, in order to inhibit uncontrolled glacier expansion in our simulation we impose an additional stepped precipitation reduction for the remainder of the stadial (20\% reduction at 2500 model years increasing to $50 \%$ reduction by 2700 model years, and returning to normal conditions by the close of the stadial) (Fig. 7A).

With the imposition of these final mass balance controls, an 'optimum fit scenario' is achieved in which model output throughout the run replicates as many of the empirical constraints as closely as possible, within the limits of model parameterization. The closeness of fit of the model through its evolution can be measured by grouping empirical reconstructions into broad climatic zones within the model domain, and by comparing these zonal areas with the simulated ice extents (Fig. 7B). Zone 1 represents strongly maritime areas, comprising Mull, Skye and Applecross. Zone 2 includes the northern icefields of Assynt and Beinn Dearg, Zone 3 is the main ice cap, Zone 4 the more arid glaciers of the Central Highlands, and Zone 5 is the southernmost glacier complex on Arran. This simple technique gives an objective measure of model fit and enables 'best-fit' time slices to be identified (Fig. 7B).

Figure 9 shows the evolution of the ice cap during the Younger Dryas period (12.9 - 11.5 ka BP) under 'optimum' conditions. Initial ice build-up occurs in many disparate seed areas across the model domain that coalesce into coherent icefields relatively quickly. Away from the main ice centre, west coast icefields in the mountains of Arran, Mull, Skye, and Assynt reach their maximum extents relatively early in the stadial, close to the climatic minimum at around 12.6-12.7 ka BP (2300-2400 model years). Around this time, the icefields of the Western Highlands begin to coalesce and give rise to an ice cap whose geometry becomes increasingly elongate under the influence of the prescribed gradients focussing precipitation over the western Highlands. Continued evolution under the scaled GRIP climate leads to progressive thickening and expansion of the west Highland ice cap, with the majority of outlet glaciers reaching positions close to empirical limits by $12.5 \mathrm{ka}$ BP (2500 model years), when the outlying 
icefields have already begun to retreat (Fig. 9). Since many of the empirical margins along the west coast of Scotland are now matched by the model almost exactly, as well as those in Wester Ross and Beinn Dearg (Fig. 8), we consider this the 'optimum fit' timeslice. Thin icefields are predicted over much of the central Highlands, consistent with empirical evidence, but few areas of thick glacier ice occur there.

In our experiments, we have achieved an optimum Younger Dryas simulation using:

1. a GRIP-forced temperature distribution scaled to a maximum mean annual temperature depression of $10^{\circ} \mathrm{C}$

2. modern precipitation values for part of the west coast and western Highlands, modified with imposed south-north and west-east precipitation reductions of $60 \%$ and $80 \%$ respectively, operating north and east of Rannoch Moor

3. low basal sliding (sliding factor $=2$ )

4. an additional stepped reduction in precipitation across the domain at the height of the stadial, from $12.5-12.0 \mathrm{ka} \mathrm{BP}$, gradually returning to present values by the end of the stadial.

The series of sensitivity tests demonstrate that the region of parameter space within which the 'best-fit' occurs is remarkably small. Experiments 1-3 show that the optimum temperature depression occurs within a range of $1-2^{\circ} \mathrm{C}$ (approximately the same as the likely error in the PDD mass balance model), optimum precipitation occurs only in a range of $\pm 5 \%$ mean annual volume, and basal sliding is prescribed to between zero and five. The sensitivity experiments show that parameter variability beyond these ranges produces ice masses that compare less well with empirical reconstructions.

Having systematically iterated the model by perturbing mass balance and dynamic parameters we have reproduced a pattern of ice extent that closely reflects empirical limits. The experiments have highlighted the manner in which ice masses evolve differently under different climate scenarios, and have shown the degree of influence that dynamic controls such as basal sliding exert on overall geometry. Despite some areas of local mismatch, the degree of overall fit is encouraging, and lends confidence to palaeoclimatic inferences drawn from the model. In particular, we are now able to retrodict likely mean annual air temperatures for the Lateglacial period, based on the scaling factor we applied to the GRIP $\delta^{18} \mathrm{O}$ ice core data (Fig. 10). 


\section{Discussion}

Recent empirical studies have shown that the Younger Dryas ice mass south of Rannoch Moor left a landsystem fingerprint consistent with that of a domed ice cap feeding steep outlet glaciers (Golledge \& Hubbard, 2005; Golledge, 2006, 2007). Such a scenario appears to be consistent with the simulated form of the west Highland ice cap at maximum conditions (Fig. 11). A major ice dome over Rannoch Moor is coalescent with a lower ice centre north of the Great Glen, together defining an elongate ice shed along the west Highland mountain chain that dominates the geometry of the ice cap. These central accumulation areas feed outlet glaciers that drain along the main valleys around the periphery of the ice cap, mostly terminating on land but with some tidewater margins along the west coast from Loch Torridon in the north to Loch Fyne in the south. The model predicts total calving losses during the height of the stadial of 1-2 $\mathrm{km}^{3} \mathrm{a}^{-1}$, of which approximately half is generated by the c. $7 \mathrm{~km}$ wide calving front in Loch Linnhe. Although our calving function is relatively crude, these results nonetheless demonstrate that this former glacier clearly played a key role in ice discharge from the central area of the main ice cap, and was probably also instrumental in sediment transport to the coast and the generation of ice-rafted debris.

During the stadial, our model predicts that the geometry of the main ice cap evolves in response to mass balance and glaciodynamic changes. A transect across the ice from west to east shows how the initial asymmetry of the ice cap changes through the stadial, as ice that had accumulated in western mountain areas subsequently converges as it flows eastward, fills Rannoch Moor, and begins to discharge via Loch Rannoch (Fig. 12). The Rannoch Glacier reaches its maximum extent around 12.1 ka BP, advancing at a mean rate of $25 \mathrm{ma}^{-1}$ through the preceding 400 years. Significantly, the advance of the Rannoch Glacier occurred mid-stadial, when aridity and gradual temperature rise leads many other margins to recede (Fig. 9). Thus its appears that the glacier responded to an internal mass balance forcing that produced climatically asynchronous behaviour. Convergent flow in the catchment of this glacier, together with its dynamic, internally forced, advance, perhaps indicates that the Rannoch Glacier played a similar mass balance role in the Younger Dryas ice cap to that of modern ice streams in contemporary ice sheets. During this advance, the ice divide over Rannoch Moor migrates 
more than $5 \mathrm{~km}$ eastward, leading to 50-70 $\mathrm{m}$ surface lowering of the Etive Glacier.

Although many areas of the model domain accurately simulate empirical glacier limits, some areas are less well-matched. Three distinct areas stand out: Kinlochewe and Loch Fannich in the far north, the Monadhliath Mountains to Glean Spean in the central Highlands, and the southeastern limits from Loch Rannoch to Loch Lomond (Fig. 13).

Around Kinlochewe and Loch Fannich the optimum model run predicts less ice than the empirical limits would suggest (Fig. 13A). Bennett \& Boulton (1993) reconstructed a coherent margin from Achnasheen northward to Loch Droma, implying that ice sourced on the hills north of Loch Fannich was coalescent with that accumulating around Torridon. By contrast, the model shows that ice accumulation on the higher ground is insufficient to infill the wide expanse of low ground that exists in this area, which effectively forms a through-valley from Loch Maree to the Cromarty Firth at Dingwall. Intriguingly the geomorphological evidence presented by Bennett \& Boulton (1993) (p138, Figure 7) shows that evidence for glacier margins is sparse in the low area north of Achnasheen, restricted in fact to a series of moraines west of Loch Fannich with no obvious source area. The survival of moraine and delta complexes around the Achnasheen lobe (Benn, 1996) has been used to constrain the geometry of former glaciers in this area, but since they remain undated it is uncertain as to whether the model is in error in this region or not.

The Monadhliath Mountains form an extensive area of upland plateau between Loch Ness and the Cairngorm Mountains (Fig. 13B), but despite the size of the area only a very limited amount of palaeoglaciological work has been undertaken in the area, largely by research students (e.g. Finlayson, 2004, 2006; Gyte, 2004). The model predictions for this area suggest that extensive ice cover of the plateau is likely to have occurred during the Younger Dryas, simply as a function of its high altitude and broad summit area (cf. Manley, 1955). Much of the snow may have been redistributed by wind, and thus it seems plausible that valley glaciers draining the high ground would have been adequately nourished to achieve extents comparable to the model simulation. However, there is considerable evidence for the former existence of glacial lakes in Glen Gloy, Glen Roy, and Glen Spean during the Younger Dryas (Sissons, 1977, 1978, 1979a; Peacock \& Cornish, 1989), which our model cannot predict. Thus whilst the possibility exists that there was a greater extent of ice in the area than currently mapped, it was 
most likely sourced from an icefield on the Monadhliath plateau that was kept separate from the western ice cap by the presence of proglacial or intralobe lakes.

Numerous glaciers drained the southeastern side of the Younger Dryas ice cap, and their limits have been the source of several differing interpretations (Thompson, 1972; Sissons et al., 1973; Horsfield, 1983; Thorp, 1986). Our model shows (above) that the Rannoch Glacier reaches its limit relatively late in the stadial, but modelled glacier configurations show significant shortcomings at Callander, Menteith and Loch Lomond, and an overprediction at Loch Tay (Fig. 13C). Limits in Glen Lyon and Balquhidder are fairly close to empirical limits. The glacier occupying Loch Lomond reached its maximal limit south of the loch some time after $12.5 \mathrm{ka}$ BP (Rose et al., 1988), but is underestimated by 10-12 km in our model. Other limits have less temporal constraint, however. In particular, the presumed limit at Callander (Thompson, 1972) is bracketed by dates at Torrie of $15.1 \mathrm{ka}$ BP and at Mollands of $12.7 \mathrm{ka}$ BP (Lowe, 1978; Merritt et al., 1990) (Fig. 2), suggesting that ice actually receded prior to the Younger Dryas. Although radiocarbon dates in recently deglaciated areas are commonly considered 'too old' due to mineral carbon contamination (Lowe \& Walker, 1980; Sutherland, 1980), in other areas they appear to be reliable (Sissons, 1967; Rose et al., 1988). If the Callander dates are in fact correct, they imply that the limit identified by Thompson (1972) relates to an earlier glacier, and thus the model may indeed be correct.

These three areas of mismatch are persistent features of the model, occurring across a breadth of parameter space far greater than the narrow 'optimum' range identified from the sensitivity tests (e.g Figs. $3 \&$ 5). We consider several possibilities to explain the discrepancies. Firstly, the lack of fit may be a result of model limitations, such as topographic smoothing, grid resolution, or simplifications of the physics governing ice flow. If this were the case, however, it would seem likely that the model would not achieve the closeness of fit that it does elsewhere. Second, it could be that the model is incorrectly parameterised, but this again seems unlikely given the degree of fit across the majority of the domain. Thirdly, our experiments run from initially ice-free conditions, and so may underestimate ice volumes in areas where large ice masses may have been inherited from deglaciation of the Main Late Devensian ice sheet. However, this would be most likely to occur in highland areas in the north, being colder, and yet the largest mismatches occur mainly in low areas in the south where ice survival is least likely. Another possibility is that local factors (that our model does not accomodate) exert a significant influence on glacier geometry. For example, the local presence of a 
highly deformable bed or large body of water may greatly reduce basal drag and thus increase sliding beyond the value prescribed in the experiments. Our topographic grid does not incorporate loch bathymetry, and with Loch Lomond reaching almost $200 \mathrm{~m}$ depth at its deepest, this may be the most likely source of mismatch in this particular area. The former Loch Lomond lobe was, however, relatively thin at its maximal extent, so although the model underpredicts its area, there may be less error in terms of total ice volume. A final consideration is that some of the empirical limits may have been misinterpreted, either in terms of their age, or with respect to the way in which landforms have been used to reconstruct and extrapolate former ice margins. Given the very localised nature of our mismatches with the empirical evidence, we consider a combination of these last two factors most likely.

\section{Synthesis}

In attempting to simulate the extent of glaciers during the Younger Dryas stadial we have gained considerable insight into the nature of ice-mass evolution in Scotland during the Lateglacial period, and the likely climatic regime that prevailed. Our model predicts that climatic deterioration during the Older Dryas (c. 14.5-13.7 ka BP) could result in the gradual build-up of ice, but is followed by recession during the initial stages of the Allerød (c. 13.7-13.1 ka BP). Subsequent regrowth of ice leads to widespread glacierization during the Younger Dryas, reaching most empirical limits by c. 12.5 ka BP. Maximum ice volume was achieved early in the stadial, after which increasing aridity leads to gradual thinning and incremental recession of many of the ice cap margins. During this period, however, the eastward-flowing Rannoch Glacier advances at a rate of $25 \mathrm{ma}^{-1}$ and alters the geometry of the ice cap sufficiently to produce a net thinning of westward-flowing glaciers such as the Etive Glacier. Very rapid deglaciation takes place at the end of the stadial, resulting in the loss of approximately $1000 \mathrm{~km}^{3}$ ice in 100 years from c. 11.7 - 11.6 ka BP, after which only small patches of inactive ice remain. The volume of melt generated during this rapid collapse of the ice cap probably led to significant jökulhlaup activity (cf Russell et al., 2003), considerable glaciofluvial erosion and sediment transport, and could have produced a sustained annual freshwater input to the oceans of around 9 billion litres per year.

Our simulation also presents a testable model for areas where empirical data is either lacking or ambiguous. For example, Fig. 8 predicts the existence of numerous 
satellite icefields and glaciers beyond the margins of the main ice cap, which in areas such as the Monadhliath and Cairngorm Mountains are far more extensive than previously recognised. It is therefore hoped that the 'optimum fit' simulation presented here may stimulate further palaeoglaciological investigations in Scotland, by offering testable glacier limits for areas where empirical data is, at present, limited. Further modelling research may be able to refine the simulation presented here, perhaps by employing a more realistic calving function, incorporating modern lake bathymetry, modelling the growth of proglacial lakes, and by adjusting the degree-day scheme to allow for greater seasonal temperature variation.

\section{Conclusions}

We have used a three-dimensional thermomechanical ice sheet model to simulate the likely glacier configuration of the Younger Dryas episode in Scotland at a higher resolution than previously possible. By systematic perturbation of the parameters governing ice accumulation and subsequent movement we have been able to accurately reproduce many of the glacier limits suggested by empirical reconstructions based on field evidence. The narrow range of parameter values that allow a simulation showing close agreement with empirical limits suggests that the model is sensitive to mass balance and dynamic perturbations. The good degree of overall fit between modelled and mapped ice margins is encouraging. Where areas of significant mismatch have been highlighted, they are most likely attributable to local variables not accomodated by the model, errors in the interpreted age of some moraines, or the presence of pre-existing ice.

These local uncertainties aside, the optimum-fit model simulation predicts that ice accumulation begins during the close of the Lateglacial Interstadial, and accelerates into the Younger Dryas achieving maximal glacier extents in the period 12.6 - 12.4 ka BP. Terminal positions in the north and west are reached earlier than those in the south and east. Basal sliding plays a limited role in Younger Dryas glacier movement in Scotland, but may have been locally enhanced where beds of easily deformable sediments occur, or where bodies of water were present. Our model predicts that mean annual temperatures at the height of the glacial phase were approximately $10^{\circ} \mathrm{C}$ lower than the Lateglacial interstadial, and precipitation was strongly focussed along the western Highland mountain chain. Modelled aridity is necessary in central and eastern Scotland in order to restrict ice build-up throughout the stadial, whereas the west probably only 
became influenced by a drier climate after c. $12.5 \mathrm{ka}$ BP.

\section{Acknowledgements}

We are particularly grateful to Rhys Cooper for construction of the digital elevation grid, and to Martin Smith and BGS Training for supporting the work. The work benefited significantly from useful discussions with numerous BGS colleagues both in the field and elsewhere. Constructive reviews by Tom Bradwell, Alison Monaghan, Christian Schoof and an anonymous referee improved the paper. NRG publishes with the permission of the Executive Director of BGS (NERC). 


\section{References}

Alley, R. B., Meese, D. A., Shuman, C. A., Gow, A. J., Taylor, K. C., Grootes, P. M., White, J. W. C., Ram, M., Waddington, E. D., Mayewski, P. A., \& Zielinski, G. A. 1993. Abrupt increase in Greenland snow accumulation at the end of the Younger Dryas event. Nature, 362, 527-529.

Alley, R.B. 2000. The Younger Dryas cold interval as viewed from central Greenland. Quaternary Science Reviews, 19, 213-226.

Arthern, R., \& Hindmarsh, R. C. A. 2003. Optimal estimation of changes in the mass of ice sheets. Journal of Geophysical Research, 108(F1, 6007), doi: 10.1029/2003JF000021.

Atkinson, T. C., Briffa, K. R., \& Coope, G. R. 1987. Seasonal temperatures in Britain during the past 22,000 years, reconstructed using beetle remains. Nature, 325, 587-592.

Ballantyne, C. K. 1983. Precipitation gradients in Wester Ross, northwest Scotland. Weather, 38, 379-387.

Ballantyne, C. K. 1989. The Loch Lomond Readvance on the Isle of Skye, Scotland: glacier reconstruction and palaeoclimatic implications. Journal of Quaternary Science, 4, 95-108.

Ballantyne, C. K. 2002. The Loch Lomond Readvance on the Isle of Mull, Scotland: glacier reconstruction and palaeoclimatic implications. Journal of Quaternary Science, 17, 759771.

Ballantyne, C. K. 2006. Loch Lomond Stadial Glaciers in the Uig Hills, Western Lewis, Scotland. Scottish Geographical Journal, 122, 256-273.

Ballantyne, C. K., \& Harris, C. 1994. The Periglaciation of Great Britain. Cambridge: Cambridge University Press.

Bard, E., Arnold, M., Maurice, P., Duprat, J., Moyes, J., \& Duplessy, J. C. 1987. Retreat velocity of the North Atlantic polar front during the last deglaciation determined by ${ }^{14} \mathrm{C}$ accelerator mass spectrometry. Nature, 328, 791-794.

Benn, D. I. 1996. Subglacial and subaqueous processes near a glacier grounding line: Sedimentological evidence from a former ice-dammed lake, Achnasheen Scotland. Boreas, 25, $23-36$.

Benn, D. I. 1997. Glacier fluctuations in western Scotland. Quaternary International, 38-9, $137-147$. 
Benn, D. I., \& Ballantyne, C. K. 2005. Palaeoclimatic reconstruction from Loch Lomond Readvance glaciers in the West Drumochter Hills, Scotland. Journal of Quaternary Science, 20, 577-592.

Benn, D. I., Hulton, N. R. J., \& Mottram, R. H. 2007a. 'Calving laws', 'sliding laws' and the stability of tidewater glaciers. Annals of Glaciology, 46, 123-130.

Benn, D. I., Warren, C. R., \& Mottram, R. H. 2007b. Calving processes and the dynamics of calving glaciers. Earth-Science Reviews, 82, 143-179.

Benn, D.I., Lowe, J.J., \& Walker, M.J.C. 1992. Glacier response to climatic change during the Loch Lomond Stadial and early Flandrian: geomorphological and palynological evidence from the Isle of Skye, Scotland. Journal of Quaternary Science, 7, 125-144.

Bennett, M.R., \& Boulton, G.S. 1993. Deglaciation of the Younger Dryas or Loch Lomond Stadial ice-field in the northern Highlands, Scotland. Journal of Quaternary Science, 8, $133-145$.

Boulton, G. S., \& Hagdorn, M. 2006. Glaciology of the British Isles ice sheet during the last glacial cycle: form, flow, streams and lobes. Quaternary Science Reviews, 25, 3359-3390.

Boulton, G. S., Jones, A. S, Clayton, K. M., \& J., Kenning M. 1977. A British ice-sheet model and patterns of glacial erosion and deposition in Britain. Pages 231-246 of: Shotton, F. W. (ed), British Quaternary Studies: Recent Advances. Oxford: Clarendon Press.

Bradwell, T. 2006. The Loch Lomond Stadial glaciation in Assynt: a reappraisal. Scottish Geographical Journal, 122, 274-292.

Braithwaite, R. J. 1995. Positive degree-day factors for ablation on the Greenland Ice Sheet studied by energy-balance modelling. Journal of Glaciology, 41, 153-160.

Brooks, S.J., \& Birks, H.J.B. 2000. Chironomid-inferred Late-glacial air temperatures at Whitrig Bog, southeast Scotland. Journal of Quaternary Science, 15, 759-764.

Brown, C., Meier, M., \& Post, A. 1982. Calving speed of Alaskan tidewater glaciers, with application to Columbia Glacier. Professional Paper 1258-C. USGS, 13pp.

Charlesworth, J. K. 1955. Late-glacial history of the Highlands and Islands of Scotland. Transactions of the Royal Society of Edinburgh, 62, 769-928.

Clapperton, C. M. 1995. Fluctuations of local glaciers at the termination of the Pleistocene: 18-8 ka BP. Quaternary International, 28, 41-50. 
Clapperton, C.M. 1997. Greenland ice cores and North Atlantic sediments: implications for the last glaciation in Scotland. Pages 45-58 of: Gordon, J.E. (ed), Reflections on the ice age in Scotland: an update on Quaternary Studies. Scottish Association of Geography Teachers and Scottish Natural Heritage.

Clark, C.D., Evans, D.J.A., Khatwa, A., Bradwell, T., Jordan, C.J., Marsh, S.H., Mitchell, W.A., \& Bateman, M.D. 2004. Map and GIS database of glacial landforms and features related to the last British Ice Sheet. Boreas, 33, 359-375.

Clark, P.U., Licciardi, J.M., MacAyeal, D.R., \& Jenson, J.W. 1996. Numerical reconstruction of a soft-bedded Laurentide Ice Sheet during the last glacial maximum. Geology, 24(8), $679-682$.

Dansgaard, W., White, J.C., \& Johnsen, S.J. 1989. The abrupt termination of the Younger Dryas climate event. Nature, 339, 532-534.

Denton, G. H., Alley, R. B., Comer, G. C., \& Broecker, W. S. 2005. The role of seasonality in abrupt climate change. Quaternary Science Reviews, 24(10-11), 1159-1182.

Finlayson, A.G. 2004. The Loch Lomond Readvance in the Creag Meagaidh area: glacier reconstruction and wider implications for the region around Glen Roy. Unpublished MSc. thesis, Royal Holloway, University of London.

Finlayson, A.G. 2006. Glacial geomorphology of the Creag Meagaidh Massif, western Grampian Highlands: implications for local glaciation and palaeoclimate during the Loch Lomond Stadial. Scottish Geographical Journal, 122, 293-307.

Finlayson, A.G., \& Bradwell, T. 2007. Evidence for Younger Dryas ice cap glaciation of the Beinn Dearg massif, northern Scotland. Quaternary Newsletter.

Glasser, N. F. 1995. Modeling the effect of topography on ice-sheet erosion, Scotland. Geografiska Annaler, 77A(1-2), 67-82.

Golledge, N. R. 2006. The Loch Lomond Stadial glaciation south of Rannoch Moor: new evidence and palaeoglaciological insights. Scottish Geographical Journal, 122, 326-343.

Golledge, N. R. 2007. An ice cap landsystem for palaeoglaciological reconstructions: characterizing the Younger Dryas in western Scotland. Quaternary Science Reviews, 26, 213-229.

Golledge, N. R., \& Hubbard, A. 2005. Evaluating Younger Dryas glacier reconstructions in part of the western Scottish Highlands: a combined empirical and theoretical approach. Boreas, 34, 274-286. 
Golledge, N. R., Fabel, D., Everest, J. D., Freeman, S., \& Binnie, S. 2007. First cosmogenic ${ }^{10} \mathrm{Be}$ age constraint on the timing of Younger Dryas glaciation and ice cap thickness, western Scottish Highlands. Journal of Quaternary Science, 22, 785-791.

Gordon, J. E. 1979. Reconstructed Pleistocene ice-sheet temperatures and glacial erosion in northern Scotland. Journal of Glaciology, 22, 331-344.

Gray, J. M. 1974. Lateglacial and postglacial shorelines in western Scotland. Boreas, 3, $129-138$.

Gray, J. M. 1978. Low-Level Shore Platforms in the South-West Scottish Highlands: Altitude, Age and Correlation. Transactions of the Institute of British Geographers, 3, 151-164.

Gray, J. M., \& Coxon, P. 1991. The Loch Lomond Stadial glaciation in Britain and Ireland. Pages 89-105 of: Ehlers, J., Gibbard, P. L., \& Rose, J. (eds), Glacial Deposits in Great Britain and Ireland. Balkema.

Gray, J. M., \& Lowe, J. J. 1977. The Scottish Lateglacial Environment: A Synthesis. Pages 163-181 of: Gray, J. M., \& Lowe, J. J. (eds), Studies in the Scottish Lateglacial Environment. Oxford: Pergamon.

Grigoryan, S. S., Buyanov, S. A., Krass, M. S., \& Shumskiy, P. A. 1985. The MathematicalModel Of Ice Sheets And The Calculation Of The Evolution Of The Greenland Ice-Sheet. Journal Of Glaciology, 31(109), 281-292.

Gyte, N. J. 2004. Late glacial landforms and climate change in the Monadhliath Mountains, Scotland. Unpublished BSc. thesis, University of Edinburgh.

Hall, A. M., \& Glasser, N. F. 2003. Reconstructing the basal thermal regime of an ice stream in a landscape of selective linear erosion: Glen Avon, Cairngorm Mountains, Scotland. Boreas, 32(1), 191-207.

Horsfield, B.R. 1983. The deglaciation pattern of the Western Grampians of Scotland. Unpublished Ph.D thesis, University of East Anglia.

Hubbard, A. 1997. High-resolution modeling of glaciers. Unpublished Ph.D thesis, University of Edinburgh.

Hubbard, A. 1999. High-resolution modeling of the advance of the Younger Dryas ice sheet and its climate in Scotland. Quaternary Research, 52, 27-43.

Hubbard, A. 2000. The verification and significance of three approaches to longitudinal stresses in high-resolution models of glacier flow. Geografiska Annaler, 82, 471-487. 
Hubbard, A. 2006. The validation and sensitivity of a model of the Icelandic ice sheet. Quaternary Science Reviews, 25, 2297-2313.

Hubbard, A., Hein, A. S., Kaplan, M. R., Hulton, N. R. J., \& Glasser, N. 2005. A modelling reconstruction of the last glacial maximum ice sheet and its deglaciation in the vicinity of the Northern Patagonian Icefield, South America. Geografiska Annaler Series A-Physical Geography, 87A(2), 375-391.

Hubbard, A., Sugden, D. E., Dugmore, A. J., Norddahl, H., \& Pétursson, H. G. 2006. A modelling insight into the Icelandic Last Glacial Maximum ice sheet. Quaternary Science Reviews, 25, 2283-2296.

Hughes, P. D., \& Braithwaite, R. J. 2008. Application of a degree-day model to reconstruct Pleistocene glacial climates. Quaternary Research, 69, 110-116.

Isarin, R.F.B., \& Renssen, H. 1999. Reconstructing and modelling Late Weichselian climates: the Younger Dryas in Europe as a case study. Earth-Science Reviews, 48, 1-38.

Jóhannesson, T., Sigurdsson, O., Laumann, T., \& Kennett, M. 1995. Degree-day glacier massbalance modelling with applications to glaciers in Iceland, Norway and Greenland. Journal of Glaciology, 41, 345-358.

Johnsen, S. J., Dahl-Jensen, D., Gundestrup, N. S., Steffensen, J.P., Clausen, H.B., Miller, H., Masson-Delmotte, V., Sveinsbjörnsdottir, A.E., \& White, J. 2001. Oxygen isotope and palaeotemperature records from six Greenland ice-core stations: Camp Century, Dye-3, GRIP, GISP2, Renland and NorthGRIP. Journal of Quaternary Science, 16, 299-307.

Jones, T. 1998. Empirical testing of Loch Lomond Stadial glacier limits derived from a glaciological model for the Applecross Peninsula, Wester Ross, Scotland. Scottish Geographical Magazine, 114(3), 164-171.

Kirk, W., \& Godwin, H. 1963. A late-glacial site at Loch Droma, Ross and Cromarty. Transactions of the Royal Society of Edinburgh, 65, 225-249.

Kroon, D., Austin, W. E. N., Chapman, M. R., \& Ganssen, G. M. 1997. Deglacial surface circulation changes in the northeastern Atlantic: Temperature and salinity records off NW Scotland on a century scale. Paleoceanography, 12, 755-763.

Laumann, T., \& Reeh, N. 1993. Sensitivity to climate change of the mass balance of glaciers in southern Norway. Journal of Glaciology, 39, 656-663.

Lowe, J. J. 1978. Radiocarbon-dated Lateglacial and early Flandrian pollen profiles from the Teith Valley, Perthshire, Scotland. Pollen Spores, 20, 367-397. 
Lowe, J. J., \& Walker, M. J. C. 1980. Problems associated with radiocarbon dating the close of the Lateglacial Period in the Rannoch Moor area, Scotland. Pages 123-137 of: Lowe, J. J., Gray, J. M., \& Robinson, J. E. (eds), Studies in the Lateglacial of North-west Europe. Oxford: Pergamon.

Manley, G. 1955. On the occurence of ice domes and permanently snow-covered summits. Journal of Glaciology, 2, 453-456.

Mayle, F. E., Bell, M., Birks, H. H., Brooks, S. J., Coope, G. R., Lowe, J. J., Sheldrick, C., Shijie, L., Turney, C. S. M., \& Walker, M. J. C. 1999. Climate variations in Britain during the last Glacial-Holocene transition (15.0-11.5 cal ka BP): comparison with the GRIP ice-core record. Journal of the Geological Society, 156, 411-423.

Merritt, J. W., Coope, G. R., Taylor, B. J., \& Walker, M. J. C. 1990. Late Devensian organic deposits beneath till in the Teith Valley, Perthshire. Scottish Journal of Geology, 26, 15-24.

Napieralski, J., Hubbard, A., Li, Y., Harbor, J., Stroeven, A. P., Kleman, J., Alm, G., \& Jansson, K. N. 2007. Towards a GIS assessment of numerical ice-sheet model performance using geomorphological data. Journal of Glaciology, 53, 71-83.

Ohmura, A., Kasser, P., \& Funk, M. 1992. Climate at the equilibrium line of glaciers. Journal of Glaciology, 38, 397-411.

Osmaston, H. A. 2005. Estimates of glacier equilibrium line altitudes by the Area x Altitude, the Area x Altitude Balance Ratio and the Area x Altitude Balance Index methods and their validation. Quaternary International, 138-139, 22-31.

Payne, A., \& Sugden, D.E. 1990. Topography and ice sheet growth. Earth Surface Processes and Landforms, 15, 625-639.

Peacock, J. D., \& Cornish, R. 1989. Glen Roy Area: Field Guide. Cambridge: Quaternary Research Association.

Peacock, J. D., Graham, D. K., Robinson, J. E., \& Wilkinson, I. P. 1977. Evolution and chronology of Lateglacial marine environments at Lochgilphead, Scotland. Pages 89-100 of: Gray, J. M., \& Lowe, J. J. (eds), Studies in the Scottish Lateglacial Environment. Pergamon.

Plummer, M. A., \& Phillips, F. M. 2003. A 2-D numerical model of snow/ice energy balance and ice flow for paleoclimatic interpretation of glacial geomorphic features. Quaternary Science Reviews, 22, 1389-1406.

Purves, R. S., \& Hulton, N. R. J. 2000. A climatic-scale precipitation model compared with the UKCIP baseline climate. International Journal Of Climatology, 20(14), 1809-1821. 
Rea, B.R., Whalley, W.B., Evans, D.J.A., Gordon, J.E., \& McDougall, D.A. 1998. Plateau icefields: geomorphology and dynamics. Pages 35-54 of: Owen, L.A. (ed), Mountain Glaciation. Quaternary Proceedings, vol. 6. Chichester: Wiley.

Rollin, K. E., Kirby, G. A., Rowley, W. J., \& Buckley, D. K. 1993. Atlas of Geothermal Resources in Europe: UK Revision. British Geological Survey Technical Report WK/95/07. British Geological Survey, Nottingham.

Rose, J., Lowe, J. J., \& Switsur, R. 1988. A radiocarbon date on plant detritus beneath till from the type area of the Loch Lomond Readvance. Scottish Journal of Geology, 24, $113-124$.

Ruddiman, W. F., \& McIntyre, A. 1981. The North Atlantic during the last deglaciation. Palaeogeography, Palaeoclimatology, Palaeoecology, 35, 145-214.

Russell, A. J., Tweed, F. S., \& Harris, T. 2003. High-energy sedimentation, Creag Aoil, Spean Bridge, Scotland: implications for meltwater movement and storage during Loch Lomond Stadial (Younger Dryas) ice retreat. Journal of Quaternary Science, 18, 415-430.

Severinghaus, J. P., Sowers, T., Brook, E. J., Alley, R. B., \& Bender, M. L. 1998. Timing of abrupt climate change at the end of the Younger Dryas interval from thermally fractionated gases in polar ice. Nature, 391, 141-146.

Shennan, I., Tooley, M. J., Green, F., Innes, J., Kennington, K., Lloyd, J., \& Rutherford, M. 1999. Sea level, climate change and coastal evolution in Morar, northwest Scotland. Geologie en Mijnbouw, 77, 247-262.

Siegert, M.J., \& Dowdeswell, J.A. 2004. Numerical reconstructions of the Eurasian Ice Sheet and climate during the Late Weichselian. Quaternary Science Reviews, 23, 1273-1283.

Sissons, J. B. 1967. Glacial stages and radiocarbon dates in Scotland. Scottish Journal of Geology, 3, 375-381.

Sissons, J. B. 1974. Late-Glacial ice cap in central Grampians, Scotland. Transactions Of The Institute Of British Geographers, 62, 95-114.

Sissons, J. B. 1977. The Parallel Roads of Glen Roy. London: Nature Conservancy Council.

Sissons, J. B. 1978. The Parallel Roads of Glen Roy and adjacent glens, Scotland. Boreas, 7, $229-244$.

Sissons, J. B. 1979a. The limit of the Loch Lomond Advance in Glen Roy and vicinity. Scottish Journal of Geology, 15, 31-42. 
Sissons, J. B., \& Walker, M. J. C. 1974. Late glacial site in the central Grampian Highlands. Nature, 249, 822-824.

Sissons, J.B. 1979b. The Loch Lomond Stadial in the British Isles. Nature, 280, 199-203.

Sissons, J.B. 1980. Palaeoclimatic inferences from Loch Lomond Advance glaciers. Pages 31-43 of: Lowe, J. J., Gray, J. M., \& Robinson, J. E. (eds), Studies in the Lateglacial of North-west Europe. Oxford: Pergamon.

Sissons, J.B., \& Sutherland, D. G. 1976. Climatic inferences from former glaciers in the south-east Grampian Highlands, Scotland. Journal of Glaciology, 17, 325-346.

Sissons, J.B., Lowe, J.J., Thompson, K.S.R., \& Walker, M.J.C. 1973. Loch Lomond Readvance in the Grampian Highlands of Scotland. Nature, 244, 75-77.

Starr, A. J. 2001. Numerical modelling of ice sheets using adaptive grids. Unpublished Ph.D thesis, University of Wales, Aberystwyth.

Sugden, D. E. 1977. Reconstruction of the morphology, dynamics, and thermal characteristics of the Laurentide Ice Sheet at its maximum. Arctic And Alpine Research, 9(1), 21-47.

Sugden, D.E., Hulton, N.R.J., \& Purves, R.S. 2002. Modelling the inception of the Patagonian icesheet. Quaternary International, 95-96, 55-64.

Sutherland, D. G. 1980. Problems of radiocarbon dating deposits from newly deglaciated terrain: examples from the Scottish Lateglacial. Pages 139-149 of: Lowe, J. J., Gray, J. M., \& Robinson, J. E. (eds), Studies in the Lateglacial of North-west Europe. Oxford: Pergamon.

Sutherland, D. G. 1993. South-west Highlands: Introduction. Pages 307 - 310 of: E., Gordon J., \& Sutherland, D. G. (eds), Quaternary of Scotland. Geological Conservation Review, vol. 6. Scottish Natural Heritage.

Sutherland, D.G. 1984. Modern glacier characteristics as a basis for inferring former climates with particular reference to the Loch Lomond Stadial. Quaternary Science Reviews, 3, 291-309.

Tarasov, L., \& Peltier, W. R. 2004. A geophysically constrained large ensemble analysis of the deglacial history of the North American ice-sheet complex. Quaternary Science Reviews, 23(3-4), 359-388.

Thompson, K.S.R. 1972. The last glaciers of Western Perthshire. Unpublished Ph.D thesis, University of Edinburgh. 
Thorp, P.W. 1986. A mountain icefield of Loch Lomond Stadial age, western Grampians, Scotland. Boreas, 15, 83-97.

van der Veen, C. J. 2002. Polar ice sheets and global sea level: how well can we predict the future? Global and Planetary Change, 32, 165-194.

Van Tatenhove, F. G. M., Fabre, A., Greve, R., \& Huybrechts, P. 1996. Modelled ice-sheet margins of three Greenland ice-sheet models compared with a geological record from icemarginal deposits in central West Greenland. Annals of Glaciology, 23, 52-58.

Weertman, J. 1964. The theory of glacier sliding. Journal of Glaciology, 5, 287-303.

Witte, H.J.L., Coope, G.R., Lemdahl, G., \& Lowe, J.J. 1998. Regression coefficients of thermal gradients in northwestern Europe during the last glacial-Holocene transition using beetle MCR data. Journal of Quaternary Science, 13, 435-445. 


\section{Table and Figure captions}

Table 1: Principal parameters used to force the ice sheet model, with their values and units.

Table 2: Modern temperature and precipitation values together with reconstructed values for the Younger Dryas, from a range of empirical studies.

Figure 1: The model domain, showing glacier limits from empirical studies published between 1955 and 2007, as well as the 'best-fit' model scenario of Hubbard (1999). Nunataks are not shown. Key dated margins and Lateglacial pollen sites provide important constraints for model experiments.

Figure 2: Oxygen isotope record (thin line) representing climate change during the last glacial - interglacial transition, from the GRIP ice core in central Greenland (Johnsen et al., 2001). Other lines show the Younger Dryas climate pattern reconstructed from chironomids in southeast Scotland (Brooks \& Birks, 2000), coleopteran fauna in the British Isles (Atkinson et al., 1987), and sea-surface temperatures calculated from foraminifera (Kroon et al., 1997) (curves shown for comparison only, and no calibration with GRIP is implied). Calibrated radiocarbon dates (Calib 5.0.2) are shown for Croftamie (overridden deposits), Mollands (postglacial sequence only), and Torrie (outside presumed Callander moraine).

Figure 3: A: Ice extents resulting from step coolings of $6-15^{\circ} \mathrm{C}$ under present precipitation conditions, and B: with imposed south-north and west-east precipitation reductions of $60 \%$ and $80 \%$ respectively, operating north and east of Rannoch Moor.

Figure 4: A: Ice extents, volumes and thicknesses resulting from step coolings of $6-15^{\circ} \mathrm{C}$ under present precipitation conditions, and B: with imposed south-north and west-east precipitation reductions of $60 \%$ and $80 \%$ respectively, operating north and east of Rannoch Moor.

Figure 5: A: Ice extents resulting from scaled coolings of $6-15^{\circ} \mathrm{C}$ applied to a 20 -year resolution GRIP temperature pattern and using the precipitation reductions from Fig. 3B, and B: ice extents for a range of basal sliding conditions under a $-10^{\circ} \mathrm{C}$ scaled GRIP pattern with imposed precipitation reductions.

Figure 6: A: Ice extents, volumes and thicknesses resulting from scaled coolings of $6-15^{\circ} \mathrm{C}$ applied to a 20-year resolution GRIP temperature pattern and using the precipitation reductions from Fig. 3B, and B: ice extents, volumes and thicknesses for a range of basal sliding 
conditions using a scaled GRIP cooling of $10^{\circ} \mathrm{C}$ and imposed precipitation reductions.

Figure 7: A: Ice growth under optimum conditions through the model run. B: Comparison of areal extent of modelled ice cover with empirical reconstructions in different parts of the domain. Note that satellite areas $(\mathrm{Z} 1,2,4,5)$ reach their best fit coeval with the GRIP climatic minimum c. 2450 model years (Fig. 2), whereas the main ice mass (Z3) achieves best fit slightly later, c. 2500 model years. 'Total' represents overall discrepancy between empirical reconstructions and modelled ice extent, across the entire domain. See text for explanation of zones.

Figure 9: Timeslices from the optimum run, showing the build-up and decay of ice across the domain during the Younger Dryas, from 12.9-11.5 ka BP (2100 - 3500 model years). Note how ice build-up is initially characterized by disparate icefields which later coalesce to form a coherent ice cap. Mid-stadial aridity leads to net marginal recession, but with local expansion of some outlet lobes, such as Loch Rannoch. Final deglaciation occurs rapidly after 11.7 ka BP.

Figure 8: Ice extent after 2500 model years - the 'optimum fit' for the majority of Younger Dryas ice masses in the domain. Most satellite icefields are at their maximum extent, and many outlet glaciers of the main ice cap are also close to their empirical terminal limits. Margins in the east and south achieve their maximum configurations somewhat later, prior to rapid deglaciation. Ice surface height values include isostatic depression.

Figure 10: Optimum-fit scaled oxygen isotope record showing equivalent mean annual Scottish palaeotemperatures during the period 15 - 11 ka BP (0 - 4000 model years), from the GRIP ice core in central Greenland (from Johnsen et al., 2001).

Figure 11: Perspective view of the 'optimum fit' scenario ice surface overlain on present topography. Note the low, domed surface of the main ice cap feeding radial outlet glaciers, and the presence of satellite icefields in Mull, Skye and the Northern Highlands. Transect line shows location of Fig. 12. Vertical exaggeration x5.

Figure 12: Cross-profile through the central portion of the Younger Dryas ice cap along the transect shown in Fig. 8. Note the change in geometry between 12.5 and $12.1 \mathrm{ka} \mathrm{BP}$, characterised by an eastward migration of the ice divide, greater extension of the Rannoch Glacier, and a surface lowering of the Etive Glacier. Dark shading illustrates topography along the flowline, light shading indicates surrounding relief. 
Figure 13: A: The area around Loch Fannich, showing model predictions compared with the empirical reconstructions (white line). Time step is 2450 years. B: The Monadhliath mountains in the Central Highlands, showing extensive plateau ice not previously mapped. Time step is 2450 years. C: The southeast sector of the main Younger Dryas ice cap, showing mismatches around the Loch Lomond, Menteith and Callander lobes. Time step is 2650 years. 
Table 1: Model parameters

\begin{tabular}{llrc}
\hline Parameter & & Value & Units \\
\hline$g$ & Gravity & 9.81 & $\mathrm{~m} \mathrm{~s}^{-2}$ \\
$\rho$ & Density of ice & 910 & $\mathrm{~kg} \mathrm{~m}^{-3}$ \\
$\rho_{w}$ & Density of sea water & 1028 & $\mathrm{~kg} \mathrm{~m}^{-3}$ \\
G_value & Geothermal heat flux & 55 & $\mathrm{~W} \mathrm{~m}^{-2}$ \\
$d$ SL & Sea level (western Scotland) & +10 & $\mathrm{~m}$ \\
A_wert & Weertman sliding parameter & $7.50 \mathrm{E}-14$ & - \\
lapse_rate & Temp / elevation relation & -0.00615 & ${ }^{\circ} \mathrm{C} \mathrm{m}$ \\
$d t$ & Time step & 0.02 & $\mathrm{a}$ \\
& cell_size & 500 & $\mathrm{~m}$ \\
& x_min & 100000 & $\mathrm{BNG}$ \\
Domain & x_max & 400000 & $\mathrm{BNG}$ \\
& y_min & 600000 & $\mathrm{BNG}$ \\
& y_max & 975000 & $\mathrm{BNG}$ \\
\hline
\end{tabular}

Table 2: Scottish Younger Dryas palaeoclimate

\begin{tabular}{|c|c|c|c|c|c|c|}
\hline Time & Location & Jan & July & Annual & Precipitation $(\mathrm{mm})$ & Source \\
\hline \multirow[t]{3}{*}{ Present } & Scotland & 2.5 & 13 & 7.5 & 1500 & \multirow[t]{3}{*}{ Met. Office (1971-2000) } \\
\hline & Dunstaffnage & - & - & 9.1 & - & \\
\hline & Model domain & - & - & 11 & - & \\
\hline \multirow[t]{5}{*}{ Younger Dryas } & Scotland & -25 & 10 & $-8--17$ & - & 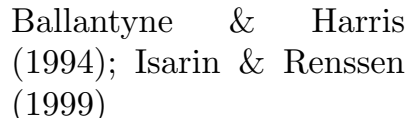 \\
\hline & NW & - & $6-7$ & - & - & $\begin{array}{l}\text { Ballantyne (1989); Benn } \\
\text { (1997); Ballantyne (2006) } \\
\text { Gray \& Lowe (1977); Sis- }\end{array}$ \\
\hline & SW & $-7--21$ & $5-7$ & $-1--8$ & $2500-2800^{*}$ & $\begin{array}{l}\text { sons }(1979 b, 1980) \text {; Gray } \\
\text { \& Coxon (1991); Ballan- } \\
\text { tyne (2002) }\end{array}$ \\
\hline & $\mathrm{SE}$ & - & 8 & - & - & Brooks \& Birks (2000) \\
\hline & $\mathrm{NE}$ & - & $6-7$ & - & $500-650$ & $\begin{array}{l}\text { Sissons \& sutherland } \\
\text { (1976); Sissons (1980); } \\
\text { Sutherland (1984) }\end{array}$ \\
\hline
\end{tabular}

* Corrected to sea level using precipitation gradient from Ballantyne (1983) 


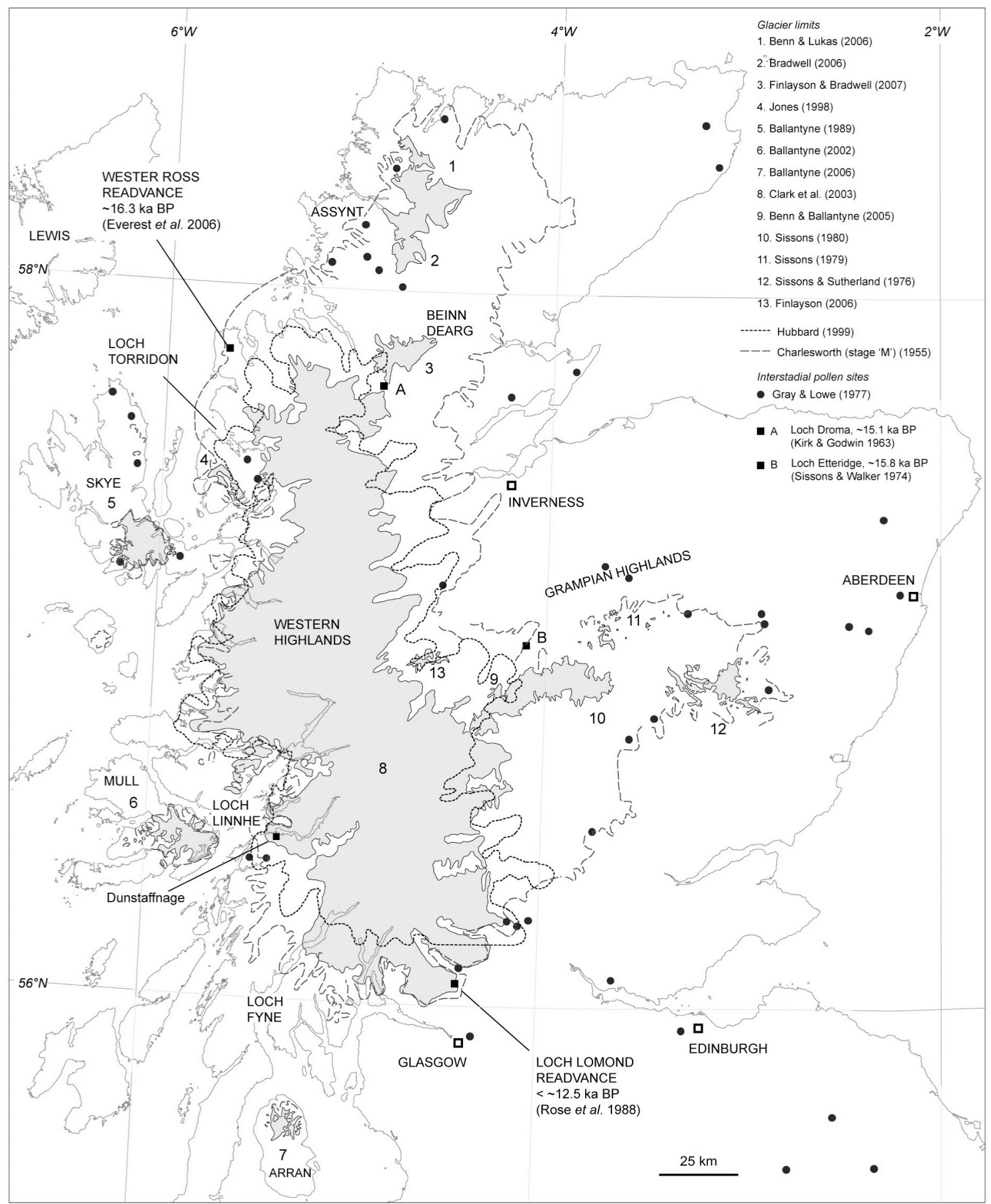

Figure 1: 


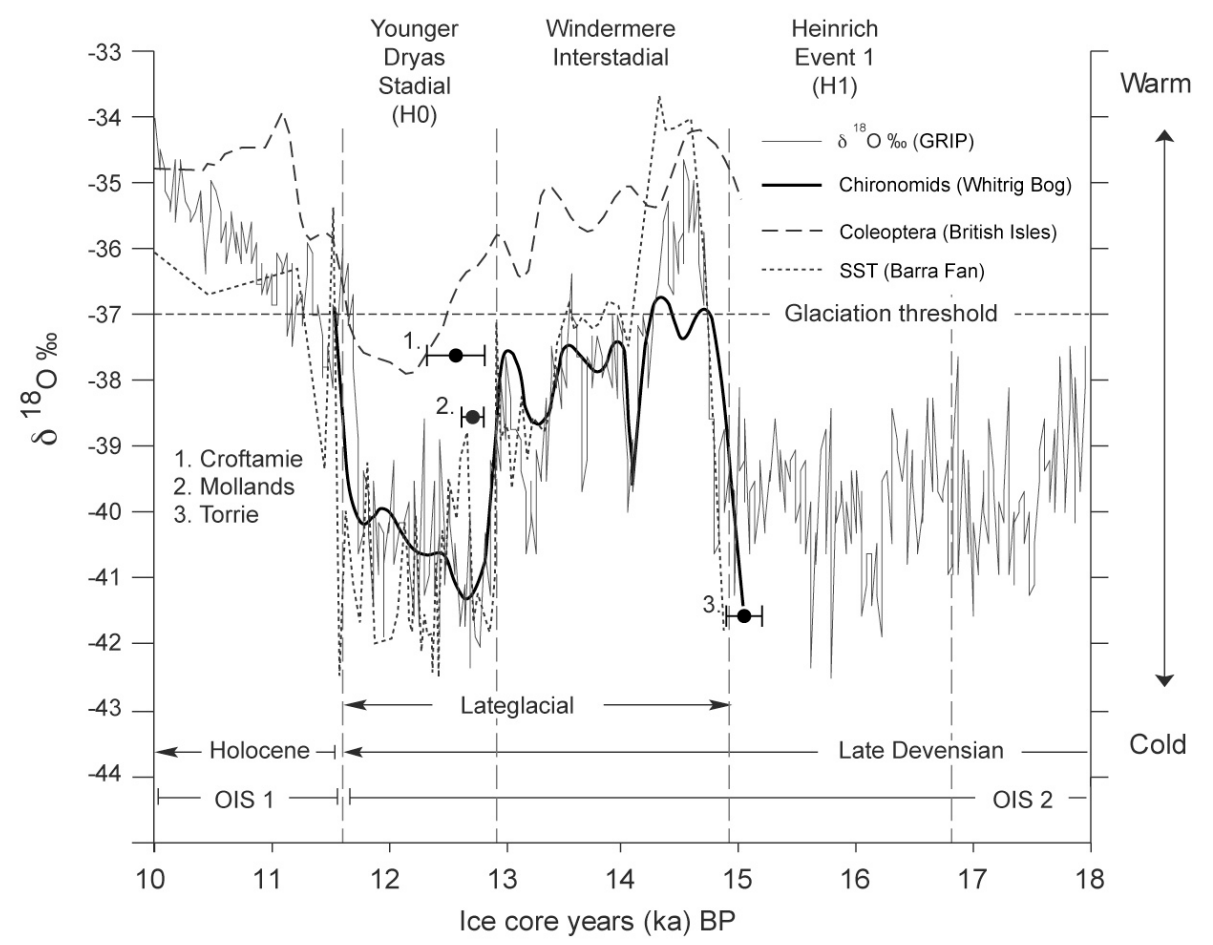

Figure 2: 

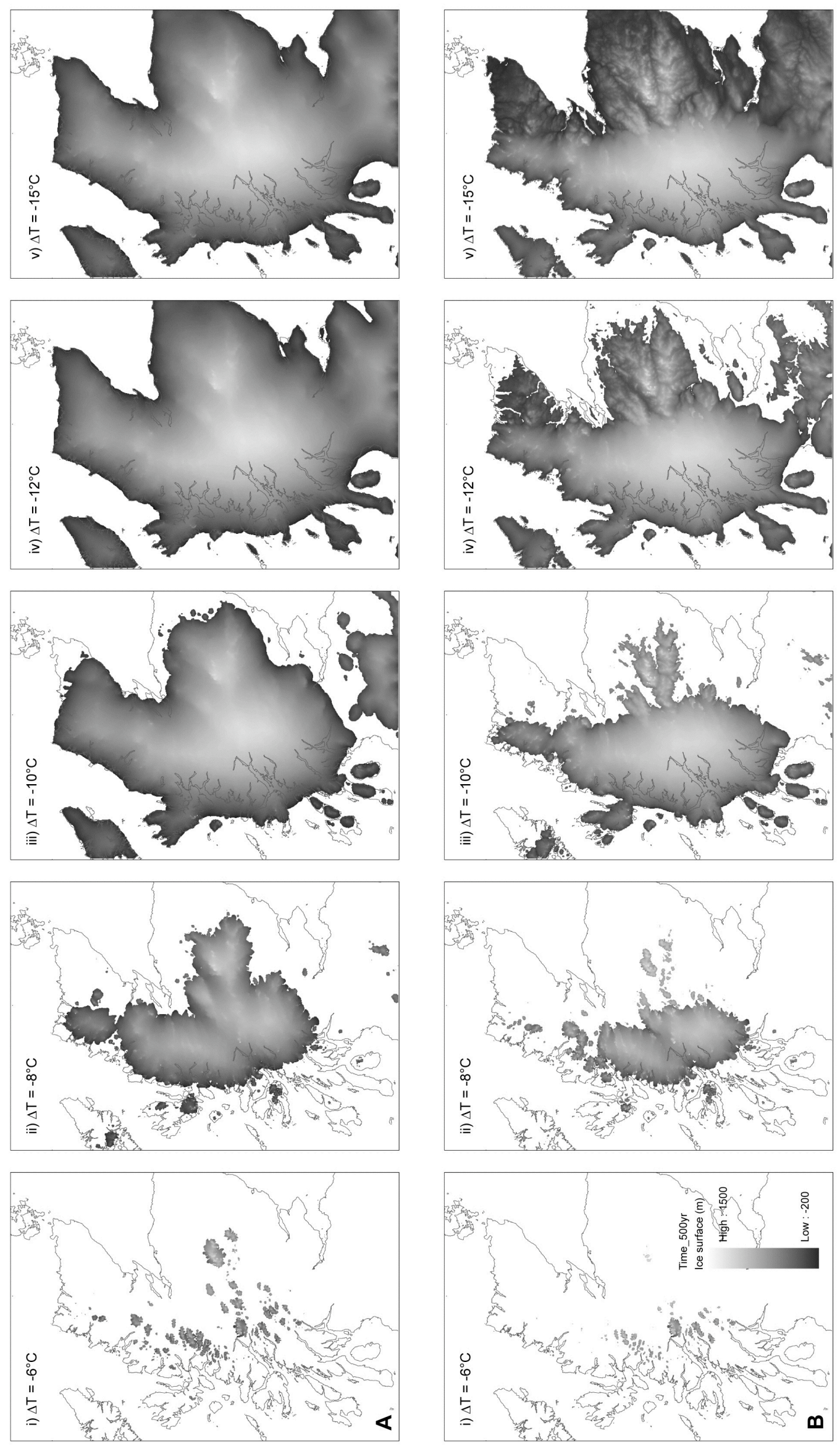

Figuße 3: 

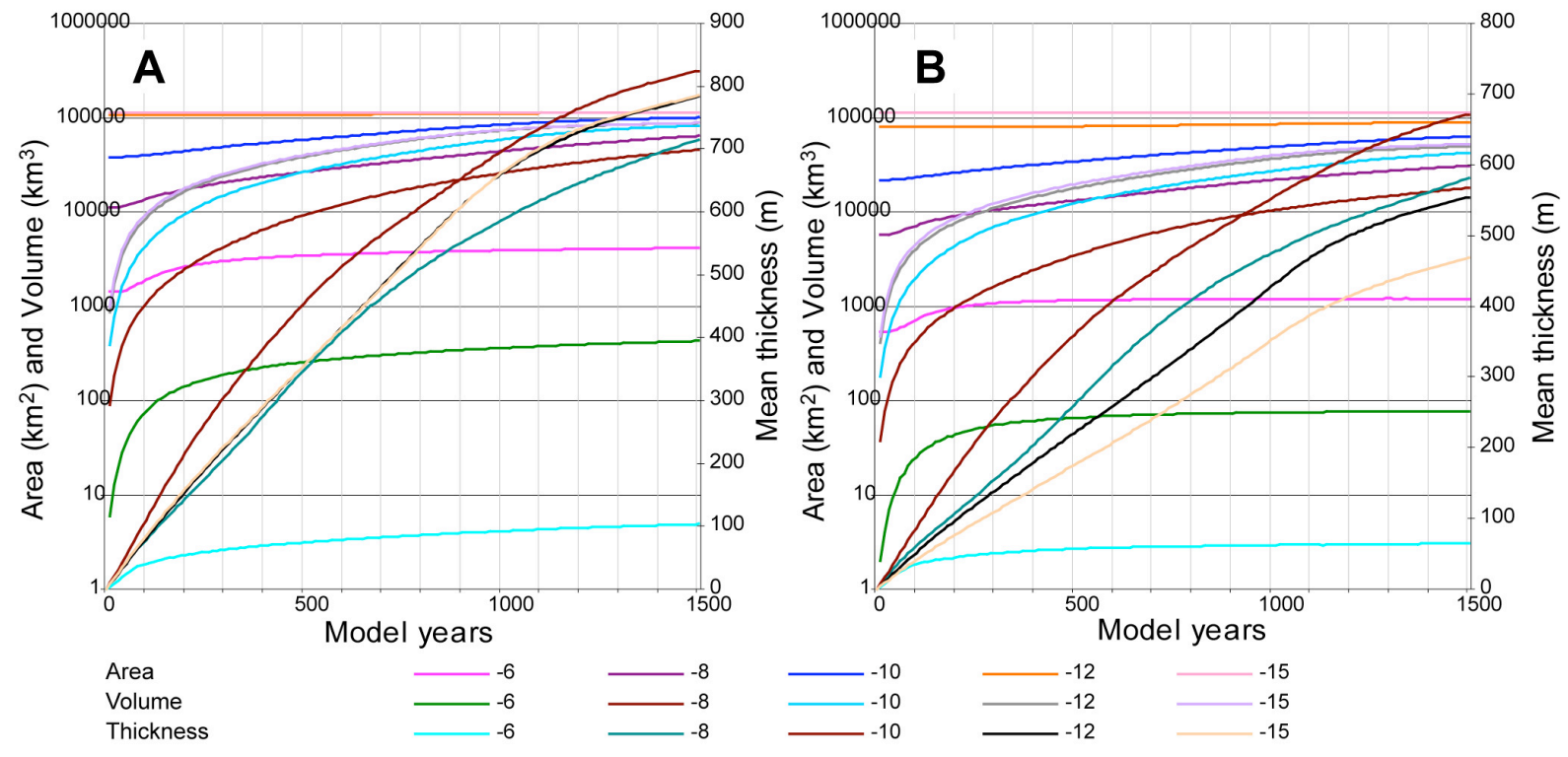

Figure 4: 

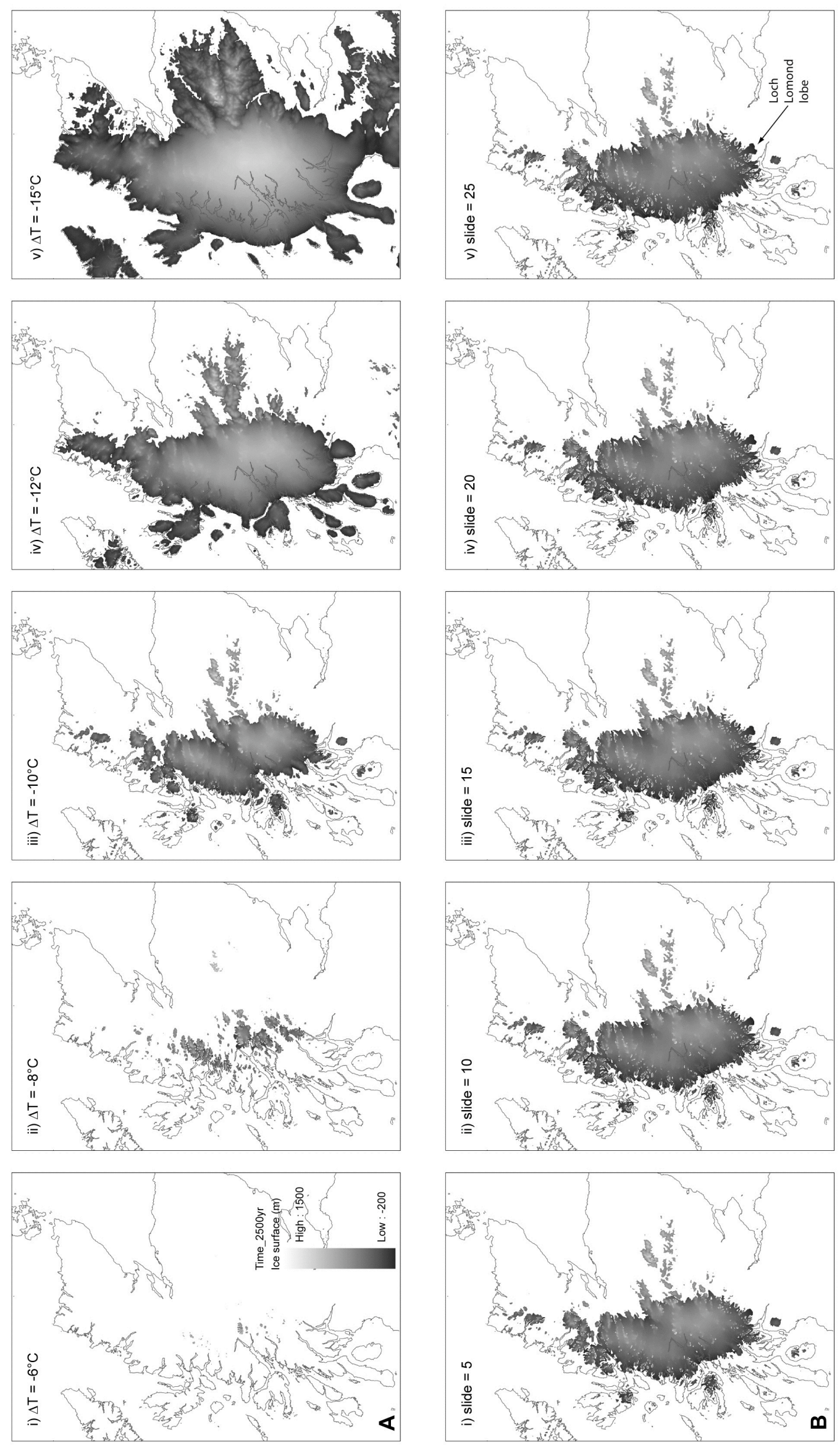

Figumre 5: 


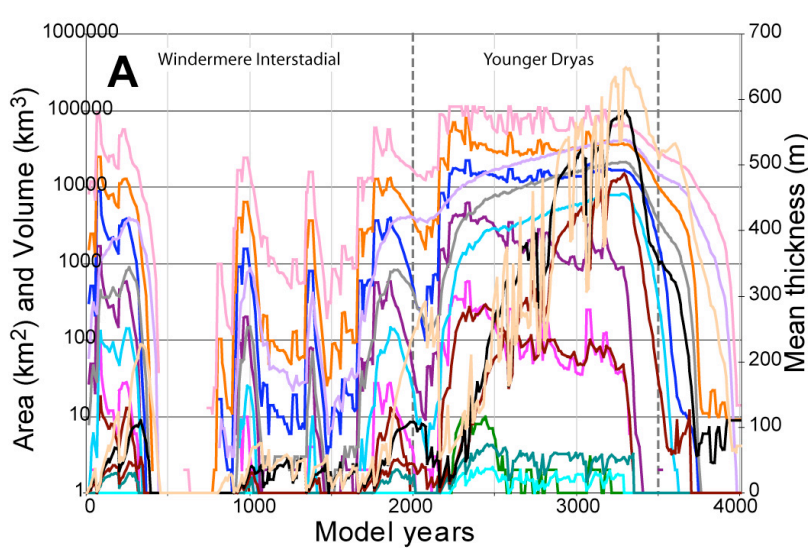

$\begin{array}{lrrrrr}\text { Area } & --6 & --8 & --10 & -12 & -15 \\ \text { Volume } & --6 & --8 & -10 & -12 & -15 \\ \text { Thickness } & --6 & --8 & -10 & -12 & -15\end{array}$

Figure 6:

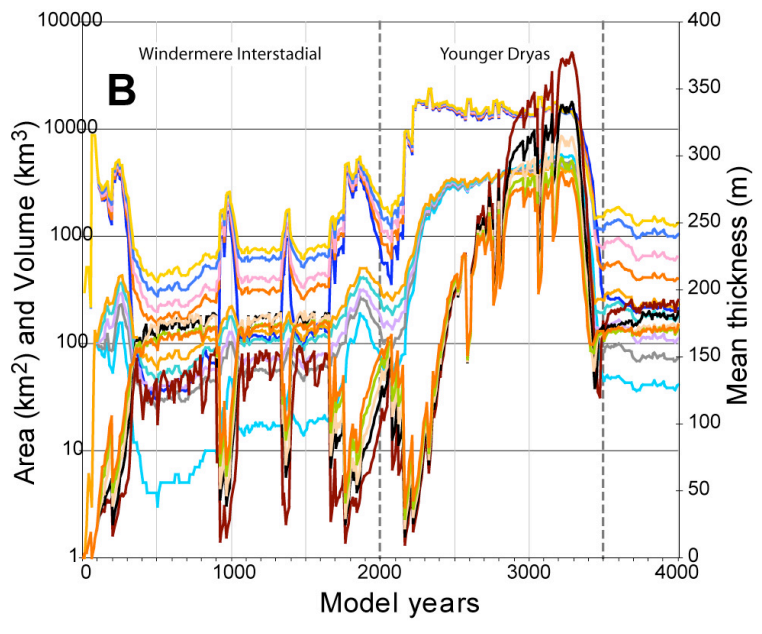

Area $\quad-5-10-15-20-25$

Volume $\quad-5-10-15-20-25$

Thickness $-5-10-15-20-25$
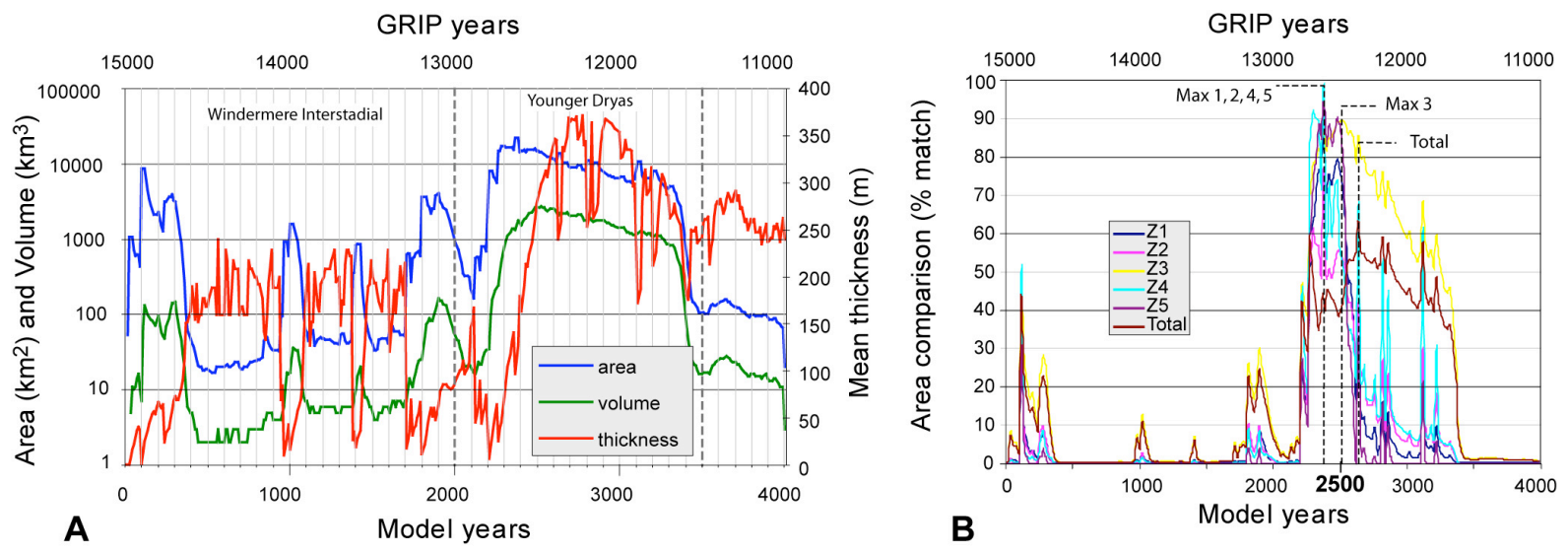

Figure 7: 

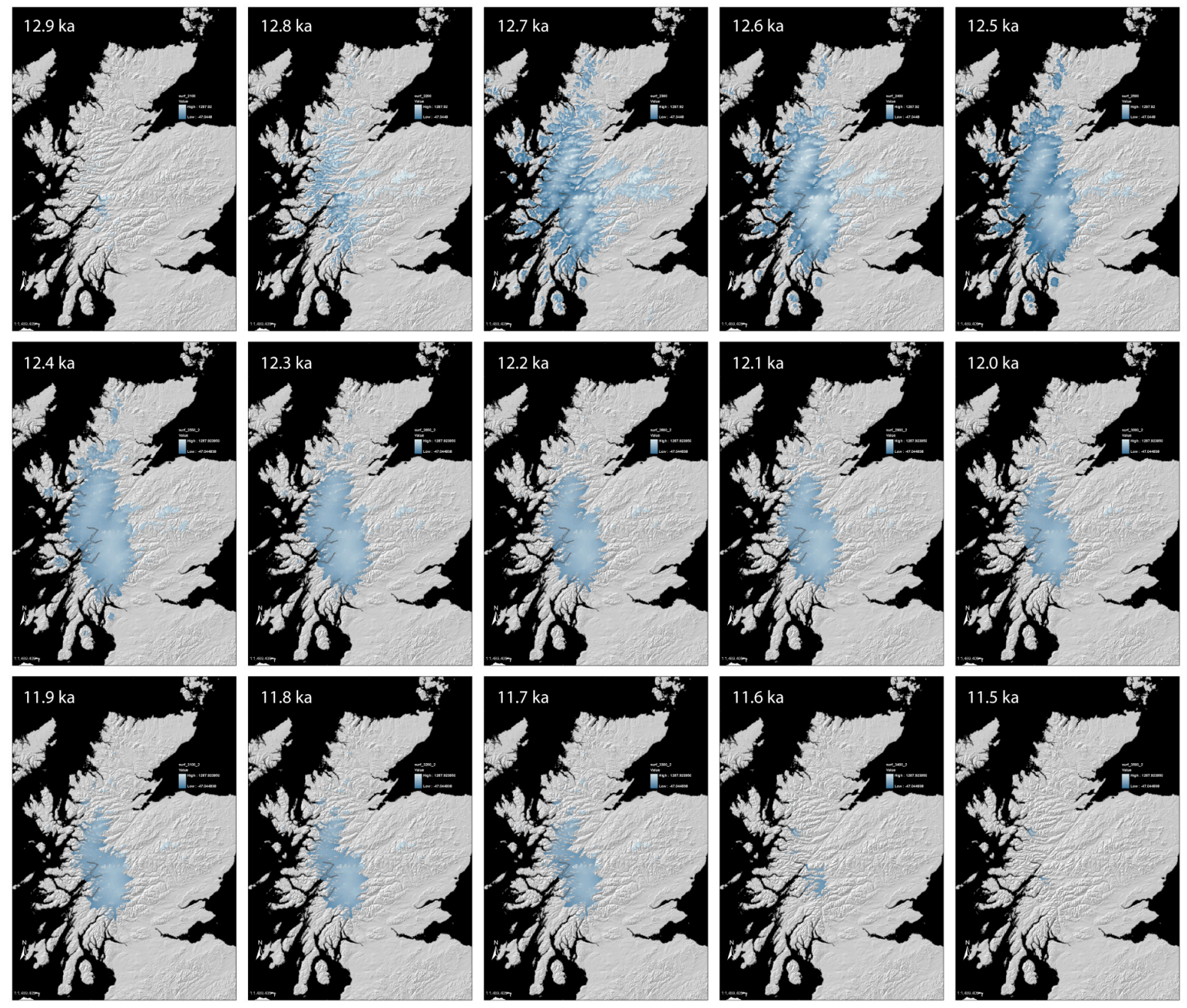

Figure 8: 


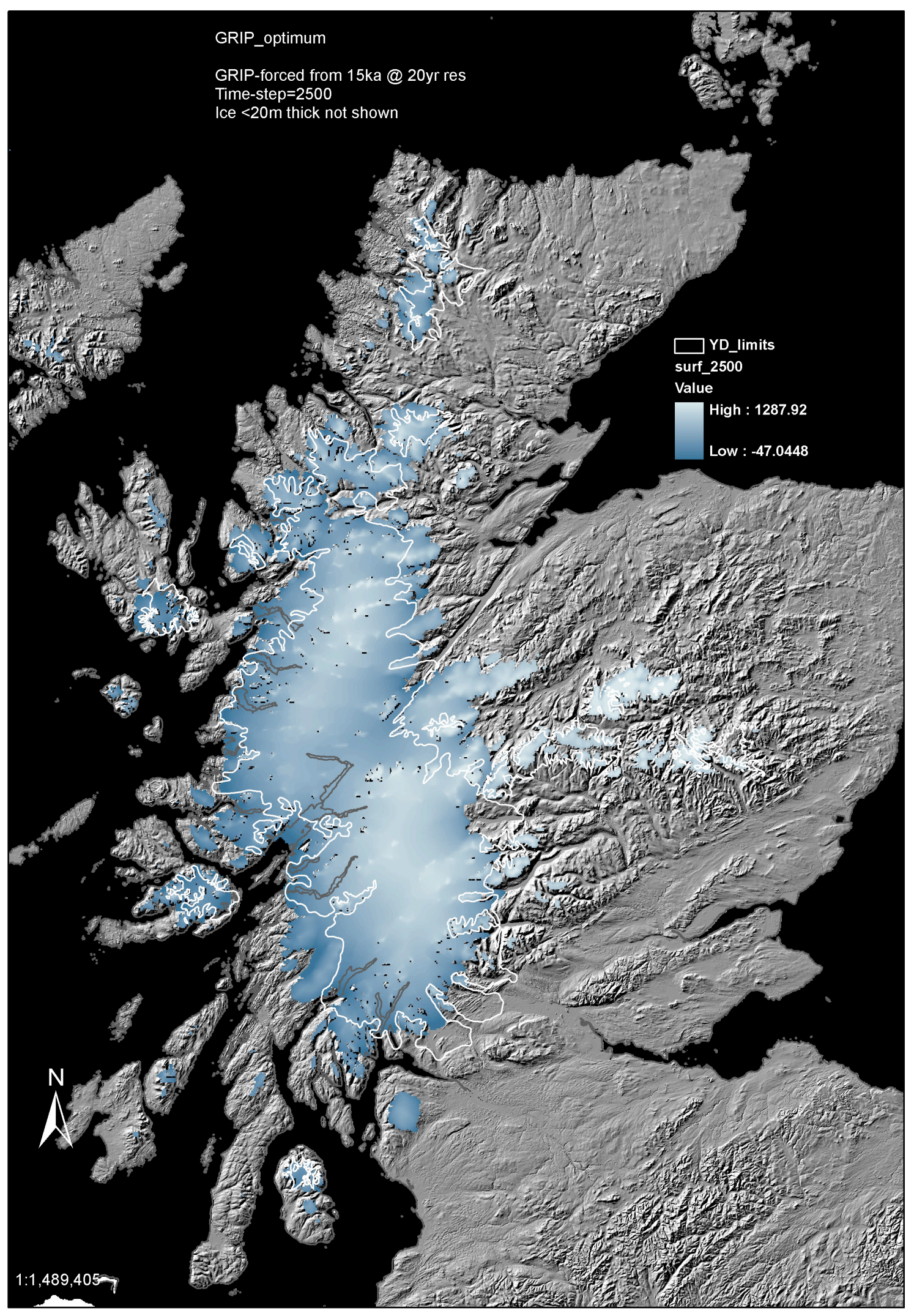

Figure 9: 


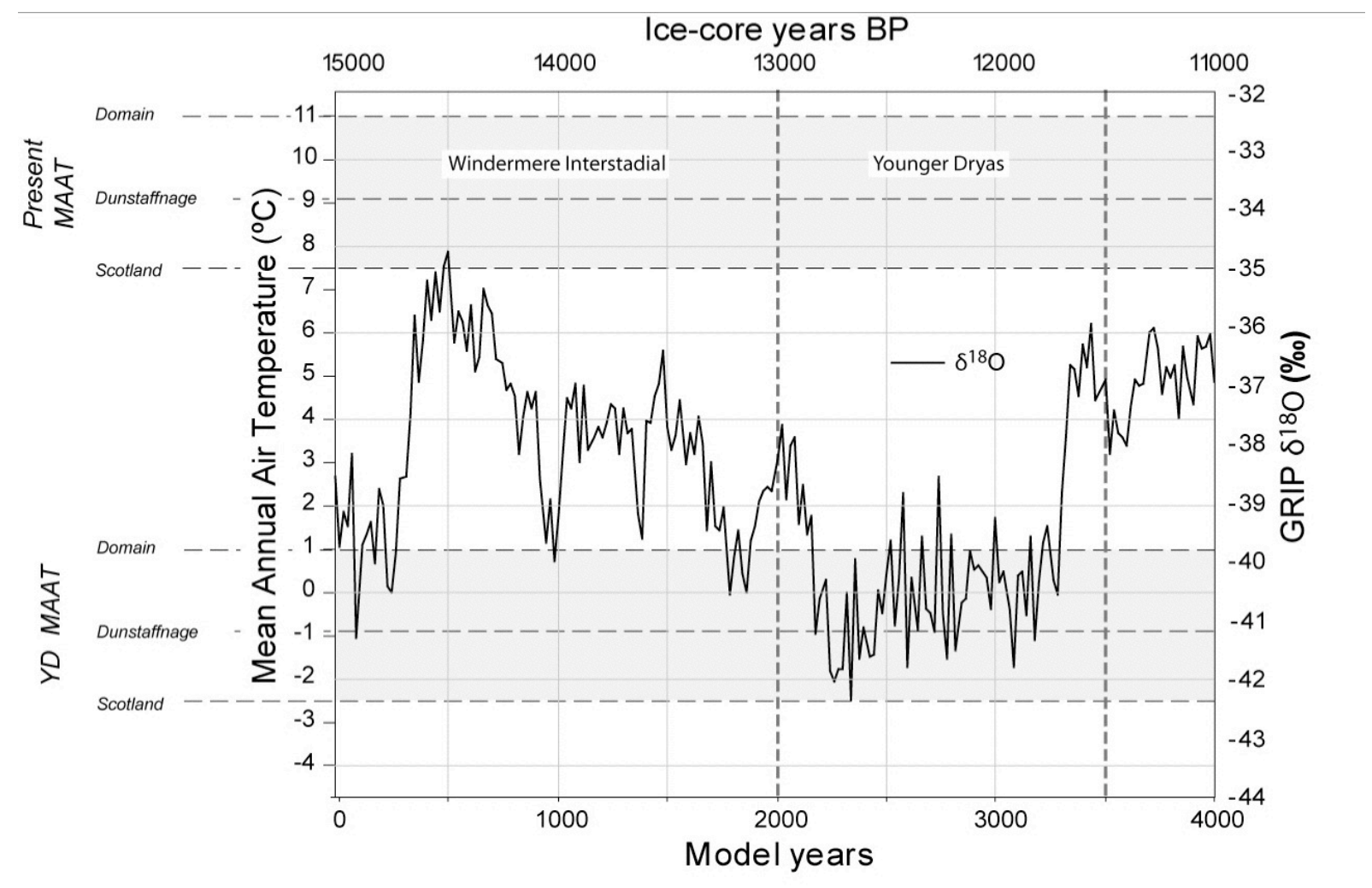

Figure 10: 


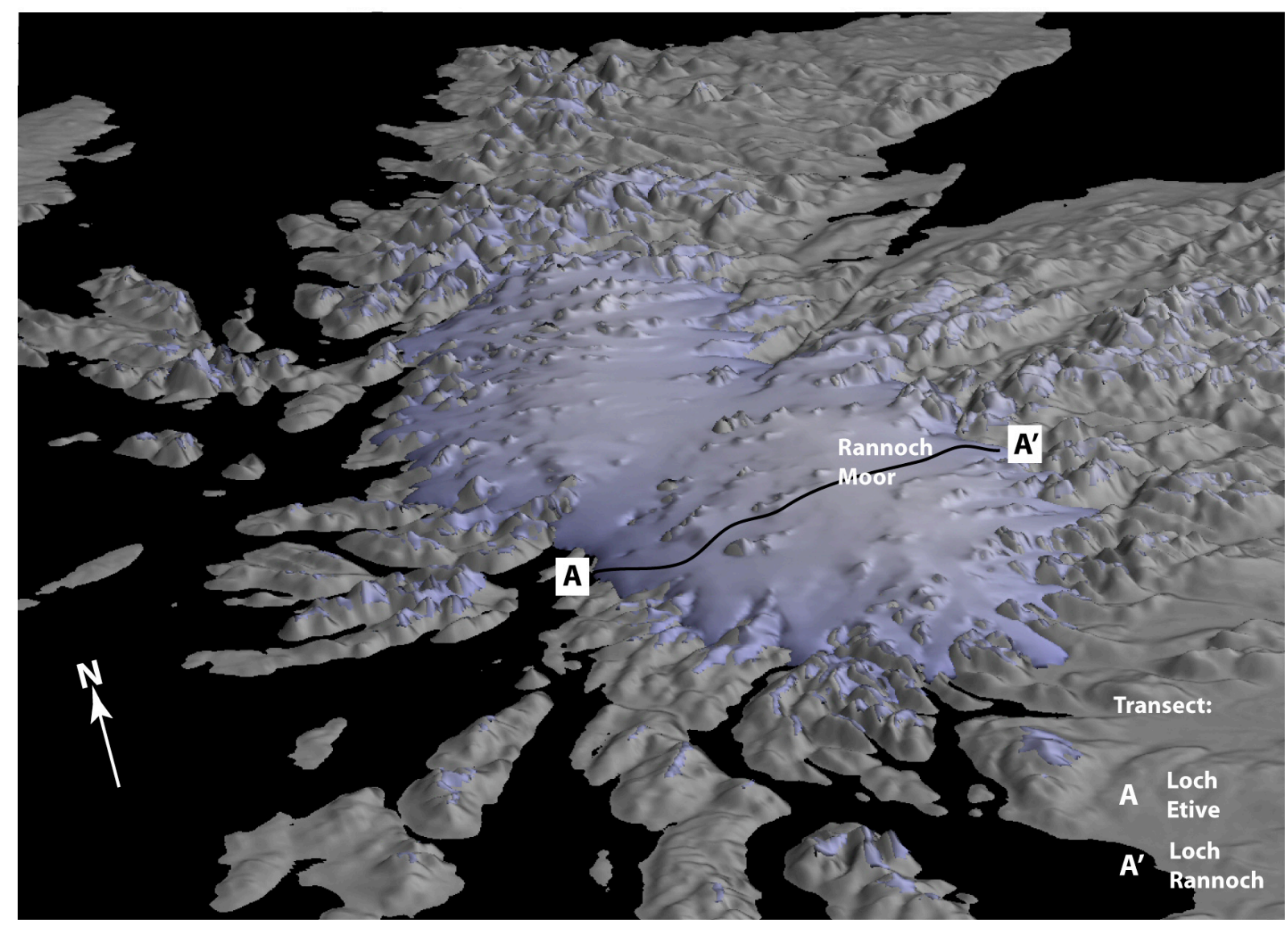

Figure 11:

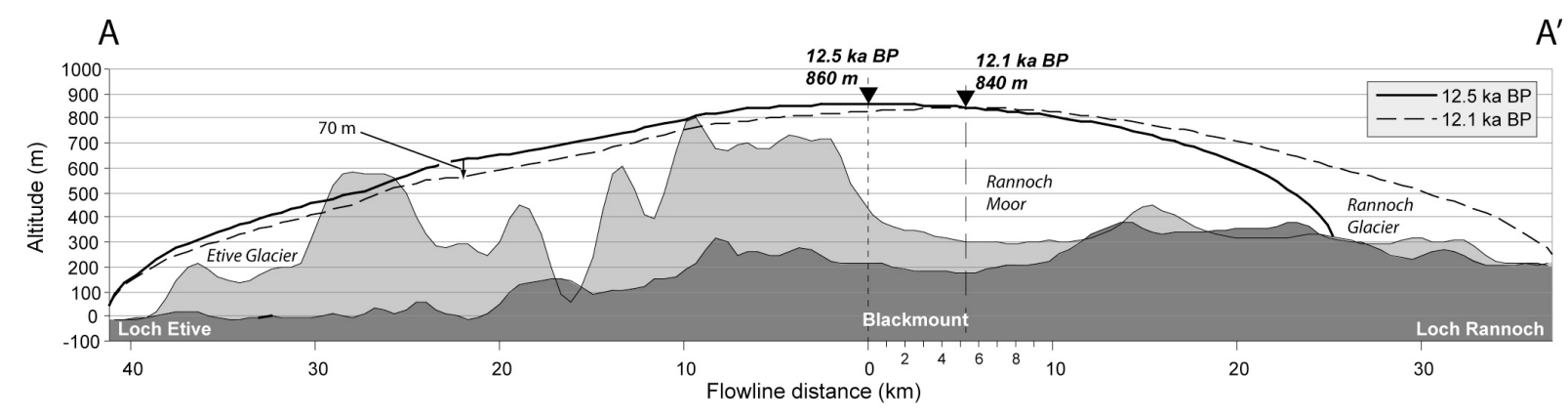

Figure 12: 

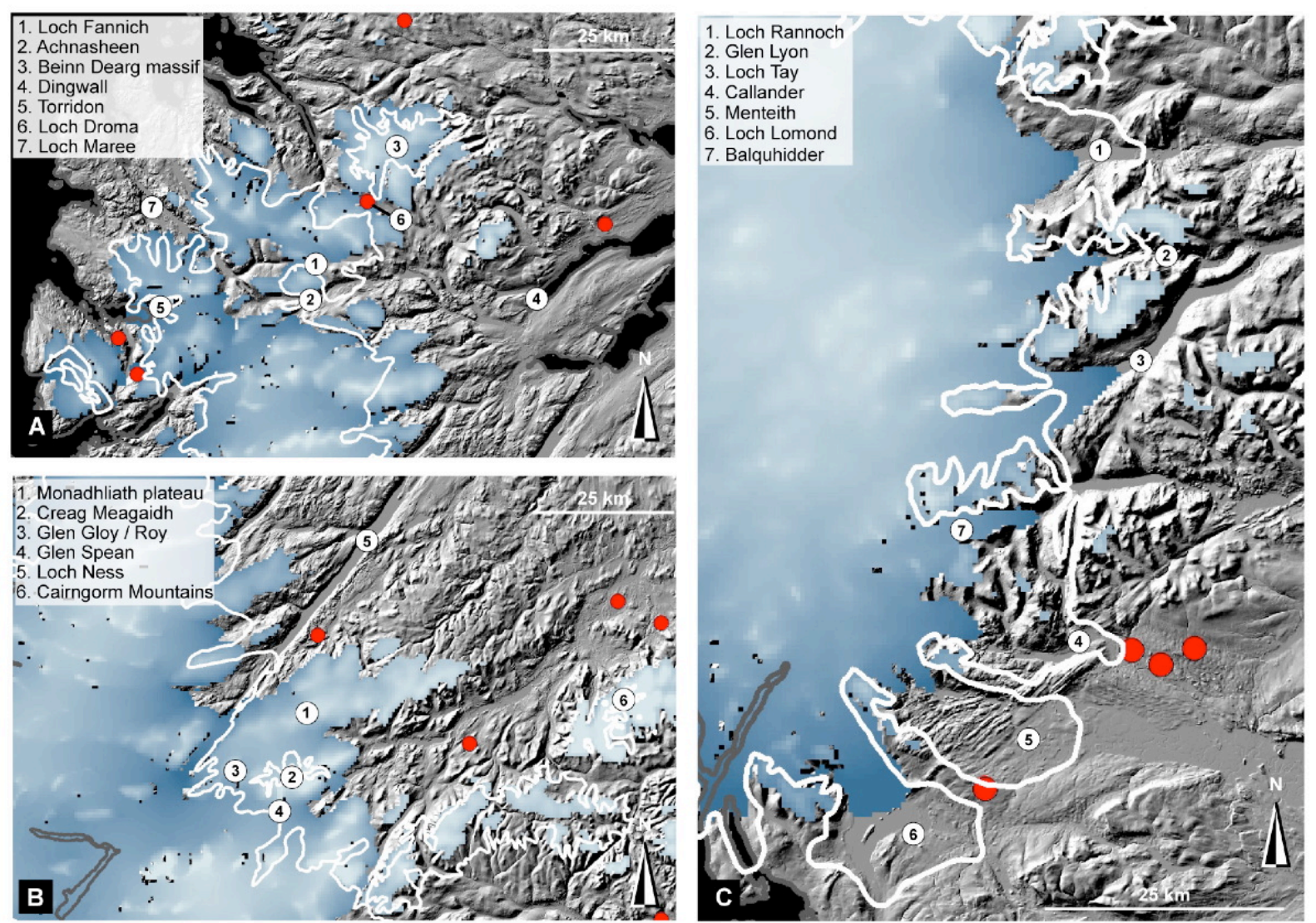

7. Balquhidder

Figure 13: 